(n) Ürat Ünersitesi Sosyal Bilimler Dergisi

The Journal of International Social Sciences

Cilt: 26, Say1: 2, Sayfa: 313-335, ELAZIĞ-2016

\title{
MADDE BAĞIMLILIĞIYLA MÜCADELEDE İNANÇ ODAKLI YAKLAŞIM: KARDELEN REHABILITASYON MERKEZİ ÖRNEĞİ ${ }^{1}$
}

\author{
Faith-Based Approach in the Fight Against Drug Addiction: Kardelen Rehabilitation \\ Center Example
}

Zahir KIZMAZ

\author{
Muhammet ÇEVIK ${ }^{3}$
}

$\mathrm{Bu}$ çalışmanın konusunu, suç ve bağımlılıkla mücadelede inanç odaklı yaklaşımın rolü oluşturmaktadır. Araştırmanın amacı, madde bağımlılığının önlenmesinde inanç odaklı yaklaşımının etkisini saptamaktır. Araştırma kapsamında, dini bir grup bünyesinde (Menzil olarak adlandırılmaktadır) Adıyaman ilinde hizmet veren Kardelen Rehabilitasyon Merkezi ele alınmıştır. Bu merkeze gönüllü olarak başvurmuş ve bu merkezde yatılı olarak kalan bireylerle yüz yüze görüşmeler yapılmıştır. Nitel bir çalışma olan bu araştırmada, madde bağımlısı olanların bu bağımlılıktan kurtulmaları için nasıl bir programa tabi tutuldukları ve madde bağımlılığının terkedilmesinde dinsel motivasyonun ve aktivitelerinin etkisi anlaşılmaya çalışılmıştır. Araştırmada, madde bağımlılığının sonlanmasında, dinsel motivasyonun, dindar akran ve çevrenin varlığının, toplum tarafından olumlanmanın ve dinsel temelde yeni bir kimlik inşasının etkili olduğu sonucu elde edilmiştir.

Anahtar Kelimeler: Madde Bağımlılı̆̆ı, Bağımlılıkla Mücadele, İnanç Odaklı Yaklaşım, Kardelen Rehabilitasyon Merkezi.

\section{ABSTRACT}

The subject of this study is the role of faith-based approach in the fight against crime and addiction. The aim of the study is to investigate the effect of faith-based approaches to the prevention of drug addiction. In the research it was dealt with the case of Kardelen Rehabilitation Center which is serving within a religious group (It refers to the community known as Menzil) in Adiyaman province. Interviews were conducted faceto-face with the individuals who have admitted voluntarily to the center and remaining as a boarder at the center. As a qualitative study, in this research it is tried to understand what kind of program the addicts were subject to in getting rid of addiction and the effect of the religious motivation and activities in the abandonment of substance abuse. In the study the results obtained are that religious motivation, the presence of religious peers and circles, affirmation by the society and the construction of a new identity based on a religious basis are effective in the termination of substance abuse.

Keywords: Substance Abuse, Struggling with Addiction, Faith-Based Approach, Kardelen Rehabilitation Center.

\section{GíRIș}

Bağımlılık günümüzün en önemli sosyal sorunlarından birini teşkil etmektedir. Gerek sigara, uyuşturucu, uçucu madde gibi bağımlılıkları gerekse internet, oyun gibi daha güncel bağımlılık türleri bireysel ve toplumsal hayatımızı tehdit etmektedir. Yaşadığımız modern dünya, özgürlüklerin en üst seviyede talep edildiği bir dünyadır. Geleneksel değerlerden ve kurumlardan sıyrılmaya eşlik eden özgürlük arayışı, serbest piyasa ekonomisi, kentleşme ve artan iletişimin yanında başta aile olmak üzere geleneksel kurumların ve değerlerin çözülmesi, Tönnisyen anlamda cemaat yaşamının ve yakın ilişkilerin zayıflaması ve bireyselleşme, bireyin sosyal yaşamdaki direncinin kırılmasına ve sosyal sorunların artmasına yol açmıştır. Modern yaşamdaki

\footnotetext{
1 Bu makale Fırat Üniversitesi Sosyal Bilimler Enstitüsü Sosyoloji Anabilim Dalı'nda 2015 yllında hazırlanan "Bağımlılıkla Mücadelede İnanç Odaklı Yaklaşım: Kardelen Rehabilitasyon Merkezi” adlı Doktora Seminerinden yararlanılarak hazırlanmıştır.

${ }^{2}$ Prof. Dr., Frrat Üniversitesi, İnsani ve Sosyal Bilimler Fakültesi Sosyoloji Bölümü ELAZIĞ zkizmaz@,firat.edu.tr

${ }^{3}$ Ar. Gör., Adıyaman Üniv. Fen-Edebiyat Fakültesi Sosyoloji Bölümü ADIYAMAN muhammetcevik@adiyaman.edu.tr
} 


\section{F.Ü. Sosyal Bilimler Dergisi 2016-26/2}

dönüşümlerle ilintili olarak toplumda bağımlılık türlerinde ve miktarında artışlar meydana gelmiştir.

$\mathrm{Bu}$ artışa bağlı olarak, bağımlılık sorununa çözüm arayışları da o denli yoğunlaşmıştır. Ancak bağımlılıkla mücadelede top yekûn başarıyı mümkün kılan herhangi bir yöntem yoktur.

Bağımlılıkla mücadele deyince akla ilk gelen tıbbi (psikiyatrik), klinik (psikolojik) ve adli (kriminolojik) yaklaşımlardır. Bağımlılık sorunu ve çözüm çabaları genel olarak bu yaklaşımların hâkimiyeti altındadır. Ancak sorunun giderek büyümesi ve komplike hale gelmesi, mevcut yaklaşımların çözüm üretmekte yetersiz kalması yeni arayışları beraberinde getirmiştir. Suç önlemede, iyileştirme çalışmalarında ve bağımlılıkla mücadelede inanç odaklı yaklaşım -geçmişte de başvurulan bir yöntem olsa dahi- günümüzde yeni bir konseptle başvurulan bir yaklaşımı oluşturmaktadır. Bu çalışmanın konusunu suç ve bağımlılıkla mücadelede inanç odaklı yaklaşım oluşturmaktadır.

$\mathrm{Bu}$ makalede, özellikle ülkemizde önemli bir etki alanına sahip olan Adıyaman Menzil Cemaati örneğinde, bağımlılıkla mücadele çalışmaları irdelenecektir. Bilindiği gibi, sözü edilen dinsel grup madde bağımlığı ile mücadelede dinsel (inanç/tasavvuf/tarikat geleneği) motivasyonu esas almaktadır.

Nakşibendî-Halidî silsilesinin bir kolu olan Menzil Tarikatı, bağlılarının içki, uyuşturucu, kumar gibi kötü alışkanlıklarını terk ettiklerine dair ülke sınırlarını aşan rivayetlerle ün kazanmış bir gruptur. Grubun, bağımlılık sorununun önemli bir kaynağı olan bu tür alışkanlıklara karşı uzun yıllar enformel bir tarzda süren çalışmalarına son bir kaç yıldır formel, kurumsal bir boyut eklenmiş durumdadır.

Menzil cemaatine mensup kişilerin kurduğu STK'ların girişimleri ve bazı kamu kurumlarının da desteğiyle "rehabilitasyon merkezleri" şeklinde açılan bu yerler bağımlılıkla mücadelede gönüllülük ilkesinin ve sivil toplum-devlet işbirliğinin bir araya geldiği yeni bir tecrübeyi oluşturmaktadır. Çalışmamızı önemli kılan bir diğer husus ise henüz yeni olan bu uygulamanın kazanılan tecrübeler ve elde edilen olumlu sonuçlara bağlı olarak tüm ülkeye yaygınlaştırılması çabalarıdır.

Uyuşturucu bağımlılarının tedavisi ve rehabilitasyonu alanında hizmet veren ve resmiyette dernek ve vakıf statüsündeki STK'lar adına açılan bu merkezler, özellikle çalışanlarının duygusal ve düşünsel bağlılıkları ile gayrı resmi anlamda Menzil Tarikatına bağlı kuruluşlardır. Merkezlerin ilkinin Şanlıurfa'da Eyvan Kültür Eğitim ve Sosyal Dayanışma Derneğince açıldığı daha sonra başarılı sonuçlar alınması üzerine Adıyaman ve Viranşehir'de benzer merkezler açıldığı öğrenilmiştir. Şanlıurfa'da dördüncü yılına giren bu merkezler, Adıyaman ve Viranşehir'de 2. yılını doldurmuştur. Tokat ilinde ise bu tür oluşumlar kuruluş aşamasındadır.

\section{ARAȘTIRMANIN YÖNTEMI}

$\mathrm{Bu}$ araştırma, betimleyici/nitel bir çalışma niteliğini taşımaktadır. Çalışma kapsamında, gözlem ve mülakatlar gerçekleştirilmiştir. Çalışmanın evreni ve örneklemi sınırlıdır. Yeni ve akademik açıdan üzerinde pek çalışılmayan bir konu olması sebebiyle nicel boyutundan çok özgün niteliğinin öne çıarılması için çaba gösterilmiştir.

Araştırma kapsamında, Adıyaman'da Kardelen İzcilik Gençlik Ve Spor Kulübü Derneği bünyesinde faaliyet gösteren Kardelen Rehabilitasyon Merkezi'nde kalan madde bağımlısı bireyler ve görevliler ile görüşülmüştür. Adıyaman'da bir buçuk yıldır faaliyette olan merkezde yaklaşık 30 kişi bağımlılık programını tamamlayıp ayrılmıştır. 10 kişilik kontenjanı olan merkezde çalışmanın yapıldığ 1 dönemde yatılı olarak kalan 8 kişiden görüşmeyi kabul eden 5 kişi ile birebir görüşme yapılmıştır.

Araştırmanın başlangıcında Kardelen Rehabilitasyon Merkezi'ne gidilerek Araştırma kapsamında katılımlı gözlem ve mülakatlar gerçekleştirilmiştir. Öncelikle rehabilitasyon 
merkezinde bulunan yetkililerden bilgiler derlenmiştir. Bu kapsamda rehabilitasyon merkezinde tam zamanlı çalışan bir öğretmen, rehabilitasyon merkezinin koordinasyonunda gönüllü olarak yer alan bir polis memuru ve "molla" adı verilen, gençlere namaz, kuran, ilmihal, tasavvuf, tarikat terbiyesi v.b. konularda eğitim veren bir kişi ile görüşülmüştür. Bu kişilerle birkaç kez yaklaşık birer saatlik görüşme yapılmıştır. Ayrıca mülakatlar yapılmadan önce uzun süreli gözlemler gerçekleştirilmiştir. İki hafta süreyle, günde ortalama 4-5 saat olmak üzere, toplamda yaklaşık 60 saatlik katılımlı gözlem gerçekleştirilmiştir. Gözlem sürecinde belli bir güven ilişkisinin tesis edilmesinin ardından merkezde kalan ve görüşmeyi kabul eden 5 madde bağımlısı gençle yaklaşık bir saat süren mülakatlar gerçekleştirilmiştir.

Mülakatlarda gençlere açık uçlu sorular sorulmuştur. Madde kullanmaya ne zaman başladıkları, hangi maddeleri hangi yoğunlukta kullandıkları, eğitim, meslek ve iş durumları, aile ilişkileri, madde kullanımından uzaklaşmak için önceki girişimleri, Menzilden ve rehabilitasyon merkezinden nasıl haberdar oldukları, merkeze gelmeye nasıl ve niçin karar verdikleri, Menzil'den beklentileri, merkezde neler yaptıkları, kuralların ve gerçekleştirilen ritüellerin kendileri için anlamları, sosyal ilişkilerinde meydana gelen değişiklikler ve rehabilitasyon merkezinden sonrasına ilişkin planları mülakatlarda sorulan sorular olmuştur. Yüz yüze görüşmelerde kişilerin anlattıkları hakkında kısa notlar alınmış. Bu notlar daha sonra temize geçirilmiştir.

Ayrıca mülakatlar gerçekleştirildikten sonra gün boyu süren bir Menzil seyahatinde gruba eşlik edilmiş, burada bağımlılıktan kurtulmak üzere Kütahya'dan Menzil'e gelen ve yaklaşık bir yıldır Menzil'de kalan M.E. adlı eski madde bağımlısı bir genç ile yaklaşık bir saat süren görüşme gerçekleştirilmiştir.

Araştırmanın tamamlanmasından sonra temize geçirilen görüşme formlarında katılımcıların farklı konulardaki ifadeleri ayrıştırılarak içeriğine göre yeniden bir araya getirilmiş, her ifadenin sonuna katılımcının adının soyadının ilk harflerini, yaşını, memleketini ve kullandığı maddeleri belirten notlar düşülmüştür.

Ayrıca Adıyaman Menzil cemaatinin inanç esaslarına, ibadet ve uygulamalarına dair ilgili kişilerden, rehabilitasyon merkezinde bulunan dokümanlardan ve internet ortamında bulunan kaynaklardan teorik bilgiler derlenmiştir.

Nakşibendilik, Hâlidiyye, tasavvuf, tarikat gibi birden fazla disiplinin ilgi alanı olan konular ile Adıyaman Menzil cemaatinin sosyolojik bir perspektiften ele alınmayı gerektiren cemaat yapısı ve faaliyetleri gibi konuların, ağırlığı nedeniyle yeterince detaylandırılamaması, konunun arka planına ilişkin teorik çerçevenin sınırlı kalmasına yol açmıştır. Kuşkusuz bu konular bağımlılıkla mücadelede inanç odaklı yaklaşımın daha iyi anlaşılmasında yararlıdır.

\section{INANÇ ODAKLI YAKLAŞIMIN TEORİK OLARAK KONUMLANDIRILMASI}

İnanç odaklı yaklaşım genel olarak cezaevlerinde bulunan suçluların rehabilitasyon ve topluma kazandırılma programları kapsamında uygulanan bir iyileştirme programıdır. ABD, bu programın kapsamlı olarak uygulanmasında önde gelen ülkelerin başında gelmektedir. Din Amerikan ceza sisteminde önemli bir yere sahiptir. Öyle ki 2003 yılı Adalet istatistiklerine göre her üç mahkûmdan biri dini programlara katılmaktadır (bkz. Park ve Akdoğan, 2011:139-140)

Din olgusunun, cezaevlerinde suçluların ıslah çalışmalarında gerekli motivasyonu sağlamada ve konformist değerlerin aktarılmasında önemli bir işlevi yerine getirdiğine hiç kuşku yok. Ancak bu araştırmada inanç odaklı yaklaşımla, ceza infaz kurumlarında bulunan suçlulara yönelik cezaevi odaklı bir iyileştirme programı niteliğinden çok dinsel grup veya merkezlerdeki etkinliklere katılmak suretiyle kriminal eğilimin sonlandırılması için dahil olunan programlar/aktiviteler kast edilmektedir.

Din ile suç arasında bir ilişkiden söz etmek mümkündür. Din ve suç ilişkisi; sosyal kontrol, sosyal öğrenme, rasyonel tercih ve sosyal ekoloji gibi kuramlar açısından ele alınabilir. Ancak dindarlık/dinsellik ve suç ilişkisinin, suç teorileri içerisinde en çok sosyal kontrol ve sosyal 


\section{F.Ü. Sosyal Bilimler Dergisi 2016-26/2}

öğrenme kuramları açısından çözümlendiği görülmektedir. Özellikle Hirschi’nin (1969) sosyal bağ (bonding) ve Aker'in (1985) sosyal öğrenme teorileri bu kapsamda öne çıkan yaklaşımlar olmaktadır. Sosyal bağ teorisine göre suçluluk, bireylerin toplumsal değer ve kurumlara (aile, din, akrabalık, eğitim v.b.) olan bağlılıklarının zayıflaması sonucunda ortaya çıkmaktadır. Bu çerçevede bağ teorisine göre; aile, okul ve bazı dini kurumlar vasıtasıyla normatif değerlerin/inançların aktarılması yoluyla bireylerin topluma olan bağlıkları ve toplumsal katılımları arttırılabilecek ve bu da onları suç işlemeye karşı korunaklı hale getirecektir (bkz. Kızmaz, 2010, Kızmaz, 2005). Aynı şekilde bu yaklaşımdan hareketle, suçlu bireylere toplumsal/dinsel değerlerin kazandırılması ve bağlılıklarının güçlendirilmesiyle kriminal yönelimlerinin de azaltılması veya sonlandırılması sağlanacaktır.

Sosyal öğrenme kuramı ise, suçluluğun bireyin temas veya iletişim halinde olduğu kriminal kaynaklardan öğrenilen bir davranış olarak görmektedir. Bu çerçevede, suç davranışının öğrenilmesinde suçlu akran grubu son derece etkili bir unsur olmaktadır. Bu çerçevede sosyal öğrenme perspektifi esas alınarak dinin, dinsel nitelikteki akran grubunun olumlu pekiştirici işlevi nedeniyle bireylerin dinsel davranış sergilemelerini sağlayarak suçta caydırıcı bir etkide bulunduğu savı ileri sürülmektedir. (Burket ve Warren, 1987). Akran grubunun etkisini formüle eden referans grup yaklaşımı, aynı referans grubu içinde yer alan bireylerin, birbiriyle benzer bir geçmiş ve inanç sistemini paylaştıklarını ve birbirlerinin davranış ve tutumlarından etkilendiklerini varsaymaktadır. Grup içerisinde olan bireyler birbirleri üzerinden davranışlarını karşılaştırma yoluna giderek ahlaki davranış sergileme ihtiyacını hissederler. Bu sebeple, referans grupları kendi içerisinde, grupsal bir denetime dönüşerek suçta caydırıcı olmaktadır (Bock, Cochran ve Beeghley, 1987: 91-92; Baier, 2001).

Sosyal öğrenme kuramına göre göre din; suçlulukta caydırıcı işlevi açısından ikili bir rol oynamaktadır: Sosyal seleksiyon ve sosyalleşme. Sosyal seleksiyon açısından din, akran grubunun seçiminde etkili bir unsur olmaktadır. Bu çerçevede dindarlık, dindar özellikler sergileyen ve dinsel öğretileri yaşantılayan nitelikteki akran grubunun seçiminde etkili olmaktadır. Sosyalleşme unsuru açısından ise din, dinsel nitelikteki akran grubunun olumlu pekiştirme yoluyla bireylerin dinsel davranış içine girmelerini sağlamaktadır. Diğer bir deyişle bu teoriler, aynı referans grubu içinde yer alan bireylerin, birbiriyle benzer bir geçmiş ve inanç sistemini paylaştıklarını ve birbirlerinin davranış ve tutumları ile biçimlendiklerini varsaymaktadır. Bu da, referans grupları kendi içerisinde, grupsal bir denetime dönüşerek, suçta caydırıcı bir etkide bulunmalarına yol açmaktadır (Baier, 2001:5).

Madde bağımlısı olan bireylerin, dindar arkadaşlar grubu içerinde bulunmaları bağımlılıktan kurtulma süreçlerinde destekleyici bir rolü yerine getirebilmektedir. Çünkü suçlu birey, sahip olduğu akran grubunun niteliğine göre uyarıcılar almaktadır. Özetle referans grubu, ahlaksal belirginliği sağlama ve kuvvetlendirme işlevini sağlayarak suçta caydırıcı bir rolü yerine getirmektedir.

Rasyonel tercih kuramının varsayımlarını esas alarak, dindarlaşmak üzerinden oluşacak olan “Allah korkusu”, “Allah’tan utanma”, “cehennem korkusu” ve "cennet ödülü” gibi duygu biçimlerinin, onları suç işlemekten caydırdığ1 görüşü ileri sürülebilir. Bu kurama göre, doğa üstü yaptırıma ve cezaya inanmanın getirdiği korku ile dinin bireylerden yerine getirmesini istediği eylemlerin gerçekleştirilmesinin karşılığında doğacak ödül beklentisinin, bireyin suç işlemekten caydırdığı düşünülmektedir. Ceza korkusu ve suçluluk ilişkisi bağlamında belirtilen bu yaklaşımlar kimi kriminologlar tarafindan "Cehennem Korkusu" (Hellfire Hypothesis) hipotezi ile de ifade edilmektedir. Cehennem korkusu hipotezine göre, dindarlık bireysel düzeyde bireyi suç işlemekten alıkoyabilen bir işleve sahiptir (Bkz. Kızmaz, 2010).

Din ve suç ilişkisi çerçevesinde öne çıkan diğer bir kuram da, dinin suç üzerindeki etkisinin toplumsal yapılara göre değişkenlik arz ettiğini ileri süren dinsel ekoloji yaklaşımıdır. Bu yaklaşıma göre dinin, suç davranışı üzerindeki caydırıcı etkisi, sapma davranışını yasaklayan sosyal değer ve normların büyük ölçüde genel kabul gördüğü toplumlar, gruplar için söz konusudur 
(Chadwick ve Top; 1993:52). Diğer bir ifade ile dinsel ekoloji kuramına göre, dinsel bağl1l1k düzeyinin düşük olduğu toplumlara/gruplara kıyasla, dinin işlevinin daha etkili olduğu toplumlarda, gruplarda veya yapılarda dinin suçtaki caydırıcı etkisi daha fazladır.

Yukarıdaki yaklaşımlar çerçevesinde madde bağımlısı olan bireylerin dindar bir çevrede yer alması ve dinsel değerlerin aktarılmasıyla suç eğiliminin azaltılabileceği öngörülebilir. Aynı şekilde din ve dindarlık, olumlu sosyal davranışları teşvik etmesi ve olumsuz veya anti-sosyal davranışların azaltması açısından suçlulukta etkilidir.

İnanç odaklı yaklaşımlar ile ilgili araştırmalar ne yazık ki henüz ülkemizde yapılmış değildir. Dahası, cezaevlerinde profesyonel düzeyde suçluların rehabilitasyonunu amaçlayan inanç odaklı programların varlığından bile söz etmek nerdeyse imkansızdır. Cezaevlerimizde sadece dini hizmetler bağlamında bazı faaliyetlerin (cezaevi imamları ve vaizlerinin din ve ahlak bilgisi dersi vermeleri, bazı dini konferanslar vermeleri, kuran öğretme ve dini kitap gönderme gibi) varlı̆̆ından söz edilebilir. Bu durum, araştırma literatürünün ülkemizde son derece sınırlı oluşunun nedenini de kısmen açıklamaktadır.

\section{MADDE BAĞIMLILIĞI İLE MÜCADELEDE BAZI YAKLAŞIMLAR}

Uyuşturucu madde bağımlılı̆̆ı ile mücadelede birincil sorumluluk alanı içerisinde sağlık kuruluşları ve ceza adalet sistemi bulunmaktadır. Ancak bu kuruluşların dışında özel klinikler ve yetkili kişiler tarafindan da bağımlılık sorunu ile mücadele konusunda destek hizmetleri verilmektedir. İlaç tedavilerinin dışında kalan psiko-sosyal yaklaşımlar, sağlık kuruluşlarında ve denetimli serbestlik uygulamalarında destekleyici olarak kullanılsa da, esas itibariyle özel kuruluşların mücadele çalışmalarında gözlenmektedir. Psikologların ve psikiyatristlerin ayrı ayrı veya birlikte açtığı görülebilen özel kiniklerde çeşitli mücadele stratejileri uygulanmaktadır.

Tedavi yöntemlerini genel hatlarıyla psiko-soysal yaklaşımlar ve ilaç tedavileri olarak ikiye ayıran Ögel tedavilerin kişiye özel olması gerektiğine ve her bağımlı için kullanılabilecek genel geçer bir tedavi yönteminin olmadığına dikkat çekmektedir (Ögel, 2010). Psiko-sosyal yaklaşımların amacı aile ve sosyal ilişkileri düzeltmek; iş, eğitim gibi sorumlulukların üstlenmesini, boş zamanlarını değerlendirmesini ve bireyin yeni beceriler kazanmasını sağlamaktır. Ögel'in tasnif ettiği psiko-sosyal tedavi yöntemlerinden bazıları şunlardır: Kısa Girişimler, Kısa Süreli Terapiler, Madde Danışmanlığı, Motivasyonel Görüşme, Kontrollü İçme Yöntemi, Bilişsel Davranışçı Terapi, Relaps Önleme, Grup Psikoterapisi, Aile Terapisi, Kendine Yardım Grupları, Terapötik Topluluklar ve Yatılı Bağımlılık Terapi Programları.

$\mathrm{Bu}$ tedavi yöntemlerinden "Terapötik Topluluklar ve Yatılı Bağımlılık Terapi Programları" içeriği açısından, araştırma konumuz içerisinde ele alınan yaklaşıma en yakın yöntemi teşkil etmektedir. "Terapötik Topluluklar ve Yatılı Bağımlılık Terapi Programları" kişinin yeni beceriler, alışkanlıklar kazanmasını, davranış biçimlerini topluluk içinde değiştirmesini ve kendisine yeni bir hayat kurmasını sağlamak amacını taşır (Ögel, 2010). Genelde bu tedavi biçimi, bir grup madde kullanıcısıyla birlikte kent dışında bir evde yapılan uzun süreli bir tedavi yöntemidir. Birçok ülkede yatılı bağımlılık terapi programları, tedavi yöntemleri içerisinde sıklıkla kullanılan ve kabul gören şeklidir. Bu yaklaşım diğer tedavi yöntemlerini de farklı seviyede içermektedir. Batı ülkelerinde uygulanan yataklı tedavi hizmetlerinin bir başka kolu da ,'Hristiyan Yardım Evleri' ve 'Sosyal Yardım Evleri'dir. Bu yöntemin üç ana aşaması vardır; Sonuç çıkarma / çevre koşullarına uydurma, tedavi ve tekrar giriş yapma (Ögel, 2010).

Sonuç çıkarma/çevre koşullarına uydurma evresi, birkaç hafta ile iki ay arası bir sürede tamamlanır. Ana evre olan tedavi aşaması; yatılı tedavi, çalışma, topluluktakilerle iletişim kurma ve toplum hiyerarşisine ayak uydurma süreçlerini içerir. Bu süreç genellikle 12 ay sürer. Tekrar giriş yapma evresi toplulukta yaşayan hastaların iş ve kalacak yer bulmalarını sağlar. Bu süreç 6 ile 12 ay arasında sürebilir. Bazı kurumlar, ana programı tamamladıktan sonra hastaların yarı-bağımsız yaşayabilecekleri “yarı-yol” evlerini işletmektedirler (Ögel, 2010). 


\section{F.Ü. Sosyal Bilimler Dergisi 2016-26/2}

Terapötik topluluk yaklaşımının olmazsa olmaz unsuru topluluktur. Topluluk, değişim sürecinin hem içinde bulunduğu sistem hem de yöntemidir. Topluluk unsuru, terapötik topluluk yaklaşımını diğer bütün madde kullanımının ve benzer bozukluklarının tedavisinde ve rehabilitasyonunda kullanılan yaklaşımlardan farklılaştırır. Terapötik topluluk yaklaşımının temelinde; sosyal rol eğitimi, temsille öğrenim ve etkinlik eğitimi gibi üç önemli psikolojik ilke bulunmaktadır. Bireylerin sosyal rollerini değiştirmek; davranış, tutum, duygu ve değerler çerçevesindeki öğrenimi etkin bir şekilde sağlayan bir yol olarak görülmektedir. Rol eğitiminin amac1, bireylere iyileşme sürecinde sosyal ve psikolojik olarak destek sağlayacak yeni davranışlar, beceriler ve tutumlar kazandırmaktır. Temsille öğrenim de, akranların ve çalışanların uygun davranış ve tutumları göstererek birer rol model olması açısından, toplum yaşamının önemli bir ilkesi olarak görülmektedir. Performans, sorumluluk, kendini değerlendirme ve özerklik yönlerinden toplumun beklentilerine ulaşabilmek kendi kendine yetkinliğin ve özgüvenin artmasını sağlamaktadır (Ögel, 2010).

Kardelen Rehabilitasyon Merkezi örneğini araştırma konusu olarak ele alan bu çalışma yukarıda belirtilen yatılı bağımlılık tedavi biçimi ile şekilsel olarak kısmen benzerlik arz etse bile, söz konusu rehabilitasyon merkezinin kendine özgü niteliklerinin de olduğu bir gerçektir.

\section{5. İNANÇ ODAKLI YAKLAŞIM ÖRNEĞİ: MENZIL CEMAATİ VE KARDELEN REHABILITASYON MERKEZI}

Burada ele alınan konunun özgün yanlarının daha iyi anlaşılması için Adıyaman Menzil Tarikatından ve tarikatın bağımlılıkla mücadeledeki özgün konumundan bahsedilecektir. $\mathrm{Bu}$ bölümde tarikat, Nakşibendilik ve Menzil Tarikatı hakkında kısaca bilgiler aktarılacak ve madde kullanma sorunu olan kişilerin Menzil cemaatine yükledikleri misyon ve Menzil'in bu alandaki konumundan söz edilecektir. Ardından geçmişten bugüne gelen tecrübenin getirdiği kurumsallaşma tecrübesi, alkol ve uyuşturucu ile mücadelede inanç odaklı yaklaşımı benimseyen Kardelen Rehabilitasyon Merkezi örneği ele alınacaktır.

\subsection{Tarikat, Nakşibendilik ve Menzil Cemaati}

Sözlükte "yol, cadde, meslek, vasıta, sebep, vesile, usul, yöntem" anlamındaki tarikat (çoğulu tarâik) terim olarak "Allah'a ulaşmak amacıyla tutulan yol, İlâhî yol" (Parlatır, 2011) demektir. Tasavvufta Hakk'a ermek için tutulan, bir takım kuralları ve ayinleri bulunan yol manasına gelmektedir (Uludăg, 1999).

Bir tarikata girmek isteyen kimsenin (tâlip, muhip) mutlaka o tarikatın şeyhine intisap (biat) etmesi gerekir. Biat tâlibin mânevî bağlılı̆̆ını ve teslimiyetini simgeler ve bu yolla şeyhin feyzinden faydalanması beklenir. Aynı zamanda şeyhe ve onun vereceği emirlere tam anlamıyla bağlı kalacağına dair söz vermeyi (ahid) ifade eden biat sırasında müride hırka ile serpuş giydirilir. Ardından mürid intisap ettiği tarikatın âdâb, erkân ve usullerini şeyhinin rehberliğinde gerçekleştirir (Öngören, 2011).

Tasavvufcu İslam anlayışını savunanlar tarikatların başlangıcını, Hz. Muhammed'in yaşadığ döneme kadar götürmektedir. Aynı şekilde Hz. Peygamber'in, başta dört halife olmak üzere sahâbîlere değişik usullerle zikir telkininde bulunduğunu savunurlar. Onlara göre, bu usullerin devam ettirilmesiyle tarikatlar meydana gelmiştir.

Menzil Tarikatı, Bekrî silsileden Naşibendiliğe bağlıdır. Menzil tarikatı esas olarak Adıyaman'ın Kâhta İlçesinin Durak (Menzil) köyünde varlığını sürdüren ancak Türkiye'nin dört bir yanından ve Avrupa ülkeleri başta olmak üzere yurtdışından yoğun rağbet gören bir dini harekettir. Bugün tarikatın başında Seyyid Abdulbaki Erol bulunmaktadır. Suriyeli Hâlidî şeyhi Ahmed Haznevî'nin halifelerinden olan babası Siirt ve Bitlis'in köylerinde uzun y1llar şeyhlik yaptıktan sonra Adıyaman'ın Kâhta ilçesinin Durak (Menzil) köyüne yerleşerek tarikat faaliyetini burada sürdürmüştür (Diyanet İslam Ansiklopedisi, 1995). Menzil'e ilk gelen babası ise de 
Menzil'deki cemaatin bugünkü durumuna ve etkisine kavuşmasına vesile olanın ve kurucusunun kardeşi Muhammet Râş̧id Erol (1930 - 1993) olduğu kabul edilmektedir.

Halka yönelik tasavvuf anlayışı ile irşad faaliyetini sürdüren Muhammed Râşid Erol'un, şeyhlik müessesesinin hâkim olduğu bir bölgenin tanınmış bir şeyh ailesine mensup olması şöhretinin kısa zamanda yaygınlaşmasını kolaylaştırmıştır. Mensuplarının içki, kumar gibi kötü alışkanlıklarını terk ettiklerine dair rivayetler dinî ve tasavvufî hayata ilgileri zayıf halk kesimleri üzerinde etkili olmuş, bunun sonucu olarak yurt içinde ve yurt dışında yaygın bir şöhret kazanmıştır. Yaşadığ 1 Menzil köyü özellikle 1975 yılından itibaren giderek artan ziyaretçi akınına uğramıştır. 1993 yılında vefatından sonra Nakşibendî - Hâlidî tarikatının Muhammed Râşid Erol tarafindan temsil edilen kolunun faaliyetleri kardeşi Seyyid Abdülbaki Erol ve halifeleri tarafından sürdürülmektedir (Diyanet İslam Ansiklopedisi, 1995).

Tarikat tarihinde, tarikatların faaliyetlerinin sürdürüldüğ̈̈ mekanlar önemli bir konuma sahiptirler (Öngören, 2011). Menzil tarikatının varlığını sürdürdüğ̈̈ Menzil (Durak) Köyü de, tarikat sayesinde önemli bir merkez konumuna yükselmiştir. Başlangıçta çok sınırlı imkânlara sahip olan köy, hâlihazırda köy tanımlamasının çok ötesinde önemli bir yerleşim ve imar durumuna sahiptir.

\subsection{Madde Bağımlılığı İle Mücadelede Menzil’in Konumu}

Menzilin başta alkol olmak üzere madde kullanım problemleri ve kötü alışkanlıkları olanlar için önemli bir yere sahiptir. Mensuplarının içki, kumar gibi kötü alışkanlıkları terk ettiklerine dair rivayetlerin halk arasında yaygın olduğu bilinmektedir. Bu durumun sonucu olarak cemaat, yurt içinde ve yurt dışında son derece yaygın bir şöhrete sahiptir. Bu rivayetler yakın ve uzak çevreden, bağlı olmayanlar arasında bile yaygındır. Mensupları arasında çok sayıda eski alkol, kumar müptelası, maddeden arındığını belirten uyuşturucu madde kullanıcısı bulunmaktadır. Araştırma için bulunulan dönemde orada bulunan cemaat müntesiplerinden kimileri görüşmelerimizde bu hususu belirtme ihtiyacını hissetmişlerdir.

Örneğin M.E. (30 Yaş, Kütahya) ${ }^{4}$ eski bir esrar bağımlısı olduğunu ifade etmiştir. Uzun yıllar esrar kullanmış, bir kaç kez yakalanmış ve mahkemeden denetimli serbestlik tedbiri almış biri olarak şunları belirtmiş̧ir:

"Yakalandım ve ceza aldım. Buna rağmen madde kullanmayı bırakamadım. Annem çok üzülüyordu, beni bu alışkanlıklardan kurtarmak için çok uğraştı. Fakat benim bırakmaya niyetim yoktu. Bir gün tanıdıklardan duymuş, "Menzil diye bir yer var, gidenler buraktyormuş, sen de git" dedi. Kabul etmedim. Burakamam dedim. Aslinda burakmak istiyordum ama bırakacağıma inanmıyordum. Sonra nasıl olduysa gelmeye karar verdim. Geldim tövbe aldım, o gün bugündür buradayım ve bir daha kullanmadım.” (M.E. 30 Yaş)

M.E. bir kaç geliş gidişten sonra temelli kalmaya karar vermiş. Bir yıldan fazla süredir Menzil'de kalmaktadır. Hizmette kalmaya karar vermiş. Bir kaç ay misafir olarak kaldıktan sora, asgari ücretle çalışmaya başlamıs. Köyden kendisi gibi dışarıdan gelip Menzil'de kalmaya karar veren bir kız ile evlenmiş. Sakal bırakmış, umreye gitmiş. Görüştüğümüzde külliye inşaatında çay ocağında çalışıyordu. "Benim gibi binlercesi var, benden sonra akrabalarımdan da gelenler oldu" demiştir.

Rehabilitasyon merkezine gelen gençler de Menzil'in halk arasında yaygın bu ünü sayesinde bu kararı aldıklarını ifade etmişlerdir. A.E. (17 yaş- İstanbul) birden fazla madde kullanan (Baly, çakmak gazı, bonzai, hap) genç bir bağımlı. Aile çevresinden Menzil'le ilgili şeyler duyduklarını, oraya gidenlerin alkol-madde gibi şeyleri bıraktığının söylendiğini, Menzil Şeyhi'nin sağlık sorunlarından dolayı İstanbul'da olduğu bir zamanda Tepeören'de sohbete katıldıklarını, sohbetten

\footnotetext{
${ }^{4}$ M.E. (30 Yaş, Kütahya) rehabilitasyon merkezinde kalan kişilerden değildir. Gözlem yapmak üzere Menzil köyüne yapılan ziyaretlerden birinde görüşülmüştür.
} 


\section{F.Ü. Sosyal Bilimler Dergisi 2016-26/2}

etkilenmesi üzerine daha fazlasını yapmaya karar verdiğini ve Adıyaman'a geldiğini ifade etmiştir. Menzil'in bağımlılar üzerindeki etkisine ilişkin basında da birçok haber bulmak mümkündür:

"Menzil denilen küçücük köye binlerce insan, zengin, fakir, ecnebi ( Alman, İngiliz) (havayolu, karayolu) akın akın gelmektedir. İşin enteresan tarafi madde bağımlıları, alkol bağımlıları gelmektedir. Bunların burada yaptıkları Tövbe ile bu kötü alışkanlıklarından kurtuldukları bilinir. Burada çaresiz kalmış bu insanlar kendilerine bir çıkış yolu bulmaktadırlar." (Becioğlu, 2014)

"Bandırma Çınarlı Mahallesinde ikamet eden 40 Roman vatandaş alkol bağımlılığından kurtulmak için Adıyaman'da bulunan Menzil Şeyhi Abdülbaki Erol'a gitti." (İlk Haber Gazetesi, 2014)

“Adıyaman'ın Kâhta İlçesi'ne bağl1, resmi adı Durak Köyü olan Menzil'e Türkiye'nin her yerinden Tövbe turları düzenleniyor. Kimi alkol ve kumardan kurtulup "Allah yolunda" yeni bir hayata başlamak umuduyla, kimi meraktan her yıl 500 bin kişi Menzil Dergâhını ziyaret ediyor." (Yeni Aktüel Dergisi y1l, 2015 )

Bunun dışında bağımlılıkla mücadelede profesyonellerin de üstesinden gelemedikleri vakalarda bağımlılara Menzile gitmelerini tavsiye ettikleri Adıyaman Denetimli Serbestlik Müdürlüğü ve Adıyaman Devlet Hastanesinde çalışan bazı uzmanlar tarafindan belirtilmiştir. Ancak hem buraya gelip yardım alan kişiler hem de hizmetlerden sorumlu konumda olanlar (mollalar, görevliler vs.) Menzil'in kişiler üzerinde etkili olmasının manevi etkinin yanında, belli koşulları yerine getirmelerine bağlı olduğunu ifade etmektedirler.

\subsection{Tecrübenin Getirdiği Kurumsallaşma Eğilimi ve Rehabilitasyon Merkezleri}

Menzil tarikatının, kötü alışkanlıkları olanların bu alışkanlıklarından kurtulmalarına yardımcı olduğuna, şifa dağıttığına dair söylemler ve pratikler çok uzun bir geçmişe dayanmaktadır. Seyyid Muhammed Raşit Erol (Ö.1993) döneminde halkta meşhur olmaya başlayan bu söylem, onun zamanında doruk noktasına erişmiş ve onun ölümünden bu yana da devam etmektedir. Ancak tarikatın bu yönü bir taraftan manevi anlamda devam ederken öte yandan zaman içinde maddi bir boyut kazanmıştır. Bağlılarının özellikle sağlık sektöründe açtıkları hastanelerle maddi anlamda da sağlık hizmetleri verdikleri bilinmektedir. Bağımlıların rehabilitasyonu konusunda da yıllardan bu yana enformel bir şekilde devam eden çalışmalar son y1llarda formel bir şekle bürünmekte ve kurumsallaşma eğilimi göstermektedir. Araştırmamıza konu edindiğimiz rehabilitasyon merkezi bu eğilimin sonuçlarından biridir.

Uyuşturucu bağımlılarının tedavisi ve rehabilitasyonu alanında hizmet veren bu kuruluşlar resmiyette dernek ve vakıf statülerinde olan STK'lar adına açılmaktadır. Menzil'in himayesinde hizmet veren bu yerlerde süreç boyunca Menzil ile düzenli irtibat sağlanmaktadır. Kurumların organizasyonu, maddi ihtiyaçlarının sağlanması, eğitim-öğretim faaliyetleri önemli ölçüde bu STK'lar aracilığıyla yerine getirilmektedir.

Adıyaman'da bulunan Madde Bağımlıları Rehabilitasyon Merkezi bir buçuk yıldır faaliyet göstermektedir. Adıyaman Kardelen İzcilik Gençlik ve Spor Kulübü Derneği'nin girişimi olarak kurulan merkez, başlangıçta Adıyaman Valiliği, Adıyaman Sağlık Müdürlüğü ve Emniyet Müdürlüğü'nün de desteğiy ile İpekyolu Kalkınma Ajansı ve SODES kapsamında kurulmuş ve bazı giderleri finanse edilmiştir.

10 kişi kapasiteli merkez çarşı içerisinde beş katlı bir binanın 3. 4. ve 5. katlarında faaliyet göstermekte, ayrıca terası da açık alan olarak bir kısım etkinlikler için kullanılmaktadır. Merkezde derslikler, mescid, yatakhane, mutfak, revir, spor salonu, resim atölyesi, ahşap oymacilık atölyesi, bilgisayar odası, televizyon odası, kütüphane ve aile görüşme odası olmak üzere çok sayıda bölüm bulunmaktadir. 
Bugüne kadar 30 kişinin Merkezdeki programı tamamlayıp ayrıldığı ancak programa ayak uyduramayıp kısa sürede ayrılanların da olduğu çalışanlar tarafindan ifade edilmiştir. Çalışmalarımızı sürdürdüğümüz dönemde rehabilitasyon merkezinde bulunan eroin bağımlısı R.'nin (18 yaş, Gaziantep) geldiğinin ilk haftasında uyum sağlayamayarak merkezden ayrıldığı gözlenmiştir. 10 kişilik kontenjanı olan merkezde, bulunduğumuz sürede 6 kişi kalmaktaydı.

Merkeze gelen kişiler, devlet hastanesinin psikiyatri servisinin tavsiyesi, emniyet çocuk şubenin yönlendirmesi ve başka yollardan haberdar olup bireysel olarak başvuranlardan oluşmaktaydı. Merkeze alınanların belli bir yaş grubunda olmasına (18-25) özen gösterilmektedir. Yaş farkının fazla olmasının baskı ve istismara yol açabileceği endişesiyle daha küçük ya da büyük yaştakiler alınmamaktadır.

Merkeze gelen bağımlıların çoğunun birden fazla madde kullanmış olduğu (baly, alkol, esrar, hap, bonzai, eroin gibi) tespit edilmiştir. Rehabilitasyon süresi yaklaşık 2-6 ay arasında değişmektedir. Ancak merkezdeki süreci tamamlayıp ayrılanların sonrasında da Menzil ve bağlıları ile irtibatlarını sürdürmeleri için çalışılmakta, gelenlerin yeni bir sosyal çevre edinmeleri ve eski sosyal çevrelerinden uzak durmaları sağlanmaya çalışılmaktadır.

Merkezde ciddi güvenlik önlemleri alınmaktadır. Binanın çıkış kapısı sürekli kilitli olup görevliler dışında başkasında anahtar bulunmamaktadır. Gündüz idari, gece ise bekçilik yapan görevliler bulunmaktadır. Ayrıca binanın tüm ortak mekânları ve çevresi kamera sistemi ile 24 saat izlenmektedir.

Bağımlılar yatılı süreçten sonra serbest yaşama dönmektedir. Ancak arınmış olanların bu dönemde de takibe, haftalık madde tarama testlerine, etkinliklere ve sohbetlere katılmaları teşvik edilmektedir.

\section{NITTEL GÖRÜŞMELER VE BU GÖRÜŞMELERIN DEĞERLENDİRILMESİ}

\subsection{Görüşmecilerin Geçmiş Yaşantıları Hakkında Kısaca Bir Değini}

Görüşme kapsamında görüşülen bireylerin ilk olarak madde kullanım geçmişlerine ilişkin bazı bilgiler verilecektir. Burada görüşmecilerin isim ve soyadlarının baş harfleri kullanılmıştır. Görüşülenler, madde kullanmaları ile ilgili aktardıkları bilgiler şu şekilde özetlenmiştir:

1. E.Ö: 17 yaşında, Adıyaman'da yaşamaktadır. 3 aydır rehabilitasyon merkezinde kalmaktadır. Geçmişte baly, esrar, alkol, eroin, bonzai, hap kullanmış. 12 yaşında 6. sınıfta iken madde kullanmaya başlamış, günlük kullanmış, kullanım miktarı gittikçe artmış ve kullandığı maddeler de değişmiş. Kullanımla birlikte torbacılık da yapmış. 15 yaşında evden uzaklaşarak şehir dışına gitmiş, orada da madde kullanmaya devam etmiş. Daha önce tedavi görmemiş, bir kez bırakma girişimi olmuş. İki ay kadar içmemiş ancak sonra yeniden başlamış. Şehir dışından dönünce kendisi gibi madde bağımlısı olan kardeşinin madde kullanmayı bıraktığını görmüş. Onun başarması ve kendisine de Menzil'e gitmeyi tavsiye etmesi üzerine bu merkeze gelmeye karar vermiş.

2. A.E.: 17 yaşında İstanbul'da yaşamakta, 3 aydır rehabilitasyon merkezinde kalmaktadır. Geçmişte baly, çakmak gazı, bonzai ve hap gibi maddeleri kullanmıştır. İlkokul 1. sınıftan itibaren sigara kullanmaya başlamış. 12 yaşında mahalle arkadaşı baly kullanırken merak edip denemiş. Sonrasında alışmış ve günlük kullanmaya başlamış. 1 yıl kadar baly kullandıktan sonra ailesi haberdar olmuş. Kısa bir süre ailesini ikna edinceye kadar bırakmış, daha sonra ailesinden gizlice tekrar kullanmaya başlamış. Daha sonra sürekli şekilde bonzai kullanmaya devam etmiş. Madde kullanımının artması üzerine işten ayrılmış ve ailesinden para çalarak kullanmaya devam etmiş. Sonra hap kullanmaya başlamış. Gittikçe artan dozlarda ve birden fazla maddeyi bir arada kullanmaya devam etmiş. Ailesi kontrol altına almaya çalışmış ancak başarılı olamamış. Aile çevresinden Menzil'le gidenlerin alkol-madde gibi şeyleri bıraktığını söyleyen akrabaları olmuş. Menzil Şeyhi'nin İstanbul'da Tepeören'de olduğu bir zamanda yanına gitmişler. Orada ilk kez 


\section{F.Ü. Sosyal Bilimler Dergisi 2016-26/2}

Şeyh'in sohbetine katılmış. Sohbetten etkilenmesi üzerine Şeyhin hizmetindeki adamların yönlendirmesiyle bu merkeze gelmiş.

3. M.K: 18 yaşında, Adıyaman'da yaşamakta ve 15 gündür burada kalmaktadır. Esrar, bonzai ve hap gibi maddeleri kullanmış. 14 yaşında okulda arkadaş çevresinden görerek ve onlara özenerek esrar kullanmaya başlamış. 16 yaşında da hap kullanmaya başlamış. Daha sonra esrar ve hapı bir arada kullanmaya devam etmiştir. Ailesinin durumdan haberdar olması üzerin, bir hafta kadar içmemiş, ancak daha sonra tekrar kullanmaya başlamış. Bir kez bırakma girişimi olmuş. 2 ay kadar kullanmamış. Yoksunluk belirtileri ve şiddet eğilimi nedeniyle yeniden başlamış. Sonra ailesi ikna etmiş ve tedavi olmaya karar vermiş. Adıyaman'da psikiyatri doktorunun tavsiyesi üzerine rehabilitasyon merkezine gelmiş.

4. M.P.: 18 yaşında, Adıyaman'da yaşamakta ve 45 gündür de merkezdeki faaliyetlere katılmaktadır. Buraya Baly ve Bonzai bağımlılı̆̆ından kurtulmak için gelmiş. Madde kullanmaya 14 yaşında baly ile başlamış. Ortaokuldan sonra okuldan ayrılmış. Problemli bir öğrenciliği varmış. Liseye devam etmek istememiş. Okulu bıraktıktan sonra oto döşemecide çırak olarak çalışmaya başlamış. Yaptığı işte baly yoğun olarak kullanıldığ 1 ve iş arkadaşı baly kullandığı için ondan görüp alışmış. Ustalarından habersiz iş yerinde kullanmaya devam etmişler. 4-5 yıl kadar baly kullanmış. 17 yaşında bonzai kullanmaya başlamış ve 1 yıl kadar devam etmiş. Bonzaiden hastanelik olunca ailesi haberdar olmuş. Madde kullandığını öğrenince ailesi ile kavga etmiş ve evden kaçmış. 1 hafta kadar dışarıda kalmış, sonra ailesinin yanına dönmüş. Ailesinin isteği üzerine rehabilitasyon merkezine gelmiş. Geldikten sonra kendisinin de fikri değişmiş.

5. A.D.: 20 yaşında Adıyaman'da yaşamakta ve 11 aydır bu merkezde kalmaktadır. Geçmişte baly, alkol, esrar ve hap gibi uyuşturucu maddeler kullanmıştır. 15 yaşında baly kullanmaya başlamış. Okula giderken okul ve mahalle arkadaşlarından görmüş, merak edip kullanmaya başlamış. Baly kullanırken bir başka suçtan denetimli serbestlik tedbiri almış ve bu süreçte 1 yıl kadar kullanmamış. DS tedbiri bitince tekrar kullanmaya başlamış. Bu defa başka maddeler de kullanmaya başlamış. Tedavi görmüş ancak tekrar başlamış. Kullandığı miktar sağlığına zarar vermeye başlayınca tekrar doktora gitmiş. Doktor hastanede yatmayı ya da rehabilitasyon merkezinde kalmayı teklif etmiş. Gelip incelemiş ve kalamayacağına karar vermiş, ancak aynı günün gecesi pek anlamlandıramadığ 1 bir şekilde fikrini değiştirmiş ve gelip burada kalmaya başlamış.

Çalışma kapsamında Rehabilitasyon Merkezinde görüşülen bireylerin genellikle benzer özelliklere sahip oldukları gözlemlenmiştir: Bu özellikler şu şekilde belirtilebilir:

a. Küçük yaşlarda madde kullanmaya başlamış oldukları,

b. Madde kullanma türlerinde bir çeşitlenmenin olduğu veya sonraki aşamada birden fazla türde uyuşturucu madde kullanıldığı,

c. Uyuşturucu alışkanlığın genelde arkadaş gruplarına özenme şeklinde başladığı,

d. Madde kullanmanın aşamalı olarak giderek daha yoğunluk kazanmaya başladığı,

e. Madde kullanma ile birlikte aile sorunlarının baş gösterdiği,

f. Madde kullanmaya başlayanların riskli sosyal ilişkiler ağı içerisinde olan bireyler olduklar1,

g. Madde kullananların okul ile ilgili sorunlar yaşamaya başladıkları,

h. Daha önce bağımlılıktan kurtulma veya bırakma girişiminde bulunup başarısız olan kişilerin merkeze geldikleri.

\subsection{Menzil'de Arınma/İyileşme Sürecinin İşleyişi}

Görüşmecilerle yapılan görüşmelerde kaldıkları rehabilitasyon merkezi ve Menzil'in manevi etkisi konusunda benzer görüşlere sahip oldukları görülmüştür. Görüşmecilerin tamamı halihazırda tarikatın şeyhinin ve ileri gelenlerinin manevi etkisi sayesinde madde kullanmaktan -uzak durabildikleri, aksi taktirde madde kullanımını terk etmelerinin mümkün olmayacağı yönünde görüşler belirtmişlerdir. 
Rehabilitasyon merkezinde yapılan gözlem ve mülakatlar neticesinde "Menzil'de arınma/iyileşme" sürecinin beş temel aşamada ele alınabileceği sonucuna varılmıştır. $\mathrm{Bu}$ aşamaların yalnızca rehabilitasyon merkezlerindeki çalışmalara özgü olmayıp, enformel bir tarzda Menzil'e kötü alışkanlıklarından ve bağımlılıklarından kurtulmak için gelen diğer kişiler için de az çok geçerli olduğu düşünülmektedir. Bu aşamalar şu şekilde belirtilebilir:

1. Farkındalık ve Karar

2. Motivasyon

3. Firsat azaltma

4. Rehabilitasyon

5. Yeniden sosyalleştirme

\subsubsection{Farkındalık ve Karar}

Kişinin bağımlılıktan kurtulması bir anda olup biten bir eylem olmaktan çok bir süreci gerektirmektedir. Bu sürecin başarıyla sonuçlanmasının yolu, kişinin içinde bulunduğu durumun olumsuzluğuna ve değişimin gerekliliğgine inanmasını gerekli kılmaktadır.

Uzmanlar değişim sürecinin farklı evrelerden oluştuğunu belirtmektedir. Kişinin değişme süreci içinde bulunduğu evreye göre yaklaşımlar da farklılık göstermektedir. Çeşitli değiş̧im modellerinden en bilineni Prochaska ve arkadaşlarının (Prochaska, DiClemente, \& Norcross, 1992) geliştirdikleri değişim modelidir. Bu modele göre değişimin farklı evreleri vardır. $\mathrm{Bu}$ evreler şu şekilde belirtilebilir

a. Farkındalık öncesi evresi (Precontemplation): $\mathrm{Bu}$ evrede kişinin yakın gelecekte davranışını değiştirmeye dönük bir niyeti yoktur. Davranışının olumsuz etkilerinin farkında bile değildir veya farkındaysa dahi davranışını değiştirmeye gereksinim duymamaktadır.

b. Farkındalık evresi (Contemplation): Bu evrede kişi davranışından kaynaklanan sorunun ciddi şekilde farkına varmıştır. Uyuşturucu kullanımının kendisini olumsuz yönde etkilediğinin farkındadır. Ancak henüz madde kullanımını bırakmayı düşünmemektedir. İnsanlar bu evrede çok uzun süre kalabilir.

c. Hazırlık evresi (Preparation): Bu evre niyet ve davranış kriterlerinin birleştiği bir evredir. Kişi madde kullanımını bırakmaya karar vermiştir fakat harekete geçmeyi ertelemektedir. Bu aşama eylem aşamasına geçmek için kişinin geçirdiği bir hazırlık dönemi olarak görülebilir.

d. Eylem evresi (Action): Kişinin sorunlarının üstesinden gelmek için davranışlarını, deneyimlerini veya çevresini değiştirmeye başladığı evredir. Eylem aşaması açık davranış değişiklikleri içerir ve zaman ve enerji kullanımı konusuna önemli bir bağll1ık gerektirir. Madde kullanımı olan kişi bundan uzaklaşmak için gerekli iradeyi göstermiş ve mücadeleye başlamıştır. Ancak bu evrede davranışın tekrar etme riski vardır.

e. İdame evresi (Maintenance): İdame evresi kişinin nüksü önlemek ve elde ettiği kazanımları pekiştirmek için çabaladığı evredir. Her ne kadar statik olarak düşünülse de bu evre değişimin sürdürüldüğü evredir. Madde bağımlısı kişi tekrar başlamamak için bir çaba göstermektedir. Bundan sonra ya madde kullanmamayı sürdürecek ve davranış değişikliği kalıcı hale gelecek veya tekrar madde kullanarak problemli davranış nüksedecektir.

Araştırma kapsamında görüşülen bireylerin çoğunun rehabilitasyon merkezine gelmeden önce madde kullanım sorunlarına ilişkin bir farkındalıklarının gelişmiş olduğu tespit edilmiştir. Çoğunlukla ailelerinin çabası ve desteği ile olsa da kendileri de belli bir farkındalık düzeyini yakalamışlardır. $\mathrm{Bu}$ nedenle görüşmecilerin hepsi bir anlamda, madde alışkanlığını terk etmek isteyip kendine güvenmeyen, karar verip nasıl davranması gerektiğini bilmeyen, daha önce bırakıp tekrar başlayan (nüks) ve hastaneye tedavi için gidip buraya yönlendirilen bağımlılardan oluşmaktadır. Görüşmecilerin farkındalık oluşumu ve düzeylerine ilişkin belirttikleri hususlar ve tespitler şu şekilde belirtilebilir: 


\section{F.Ü. Sosyal Bilimler Dergisi 2016-26/2}

1. E.Ö.: Uyuşturucu madde kullanmayı bırakmak için bir kez girişimde bulunmuş. İki ay kadar içmemiş ancak sonra yeniden başlamış. Şehir dışından dönünce kendisi gibi madde bağımlısı olan kardeşinin madde kullanmayı bıraktığını görmüş.

"Daha önce kardeşim burada tedavi gördü, o başarınca ben de kalmaya karar verdim. $O$ buraya girdiğinde ben dışarıda idim. Geldim baktım bırakmış, namaza başlamış. O zaman ben de karar verdim.” (E.Ö. 17 yaşında)

2. A.E.: Uyuşturucu maddeyi bırakmasında ailesinin etkili olduğunu belirtmiş, madde kullanmanın kendisine verdiği zarardan çok ailesine verdiği zararı sorun olarak görmüştür.

“Ailem kullandığımı tekrar fark ettikten sonra bırakmak istedim. Onlar üzülmesin diye. Bir de sürekli paralarını çaldı̆̆ım için bırakmak istiyordum. Onlar olmasaydı bırakmayı düşünmüyordum." (A.E. 17 yaşııda)

3. M.K.: Bir kez bırakma girişimi olmuş. 2 ay kadar kullanmamış ancak yeniden başlamış. Bırakmaya karar vermesinde ailesinin kendisini ikna etmesinin rolünü vurgulamıştır. Hastane tedavisinden buraya yönlendirilmiş.

"Bir kez bırakmaya çalıştım, 2 ay kadar kullanmadım, etrafima zarar veriyordum, bu nedenle yeniden başladım. Ailem tekrar kullandığımı öğrenince sert tepki verdi. Bana ve aileme zarar verdiğini düşündüm. Sonra ailem beni ikna etti ve tedavi olmaya karar verdim. Adıyaman'da psikiyatri doktorunun tavsiyesi üzerine buraya geldim.” (M.K. 18 yaşında)

5. M.P: O da konuya ilişkin şunları belirtmiştir:

"Kullandığım dönemde günde 2 kez kullanıyordum. Ara verdiğim hiç olmadı. Bırakmayı düşünmüyordum. Ailem istedi, geldikten sonra ben de fikrimi değişstirdim. Burada anlatılanlardan sonra kötü yolda olduğumu ve bu işten uzaklaşmam gerektiğini düşünmeye başladım" (M.P. 18 yaşıında).

5. A. D.: Baly kullanırken bir başka suçtan denetimli serbestlik tedbiri almış ve bu süreçte 1 yıl kadar madde kullanmamış. DS tedbiri bitince tekrar kullanmaya başlamış. Bu defa başka maddeleri de kullanmaya başlamış.

“Geçen yaz bırakmaya çalışsım, doktora gittim, ilaç verdi. İlaçları kullanmayı bıraktım. Sonra tekrar madde kullanmaya başladım. Aşırı kullanımdan ağzım yüzün şsişmeye başlayınca tekrar doktora gittim. Doktor bu rehabilitasyon merkezinden bahsetti. Hastanede yatmayı ya da burada kalmayı önerdi. Buraya gelip baktım, 'kalmam' dedim. Gece eve gidip yattım. Ne olduysa o gece oldu, sabah kalkınca anneme 'kalk gidelim' dedim ve gelip burada kalmaya başladım." (A.D. 20 yaşında)

Yukarıdaki anlatımlara bakıldığında, gençlerin çoğunun madde kullanımından uzaklaşmak, bağımlılıktan kurtulmak için istekli oldukları ve bunun için çabaladıkları anlaşılmaktadır. $\mathrm{Bu}$ durum, araştırma kapsamındaki bireylerde uyuşturucu madde kullanmayı terk etme noktasında belirli bir düzeyde farkındalık oluştuğunu göstermektedir. Bu kapsamda, madde kullanma alışkanlığından kurtulmak için zaman zaman girişimlerde bulunulduğu ve bazılarında bu girişimin başarısızlıkla sonuçlandığı dikkat çekmektedir. Bundan sonraki aşamada yapılması gereken şey, terk etme yönünde daha güçlü motivasyonun oluşturulmasıdır. Bunun için ikinci aşamaya geçmek gerekmektedir. Din ve inanç odaklı yaklaşımın etkisi de en çok bu aşamada devreye girmektedir.

\subsubsection{Motivasyon}

Kardelen Rehabilitasyon Merkezinin bireylerin uyuşturucu madde bağımlılı̆̆ veya alışkanlığını sonlandırma konusunda oynadığg rol, önemli ölçüde dinsel niteliktedir. Özellikle dini temellerden beslenen terk etme yönündeki motivasyon son derece başat bir rol oynamaktadır. Kardelen Rehabilitasyon Merkezinde uygulanan yöntemi diğer psiko-sosyal tedavi yöntemlerinden farklı kılan ise, bu merkezin Menzil tarikatı ile bağlantılı olmasıdır. 
Buraya gelenler kullandıkları uyuşturucu maddeler ve İslam dışı yaşam için genelde pişmanlık duygusunu, arınma ve yenilenme ihtiyacını güçlü bir şekilde hissetmektedirler. Bu nedenle bu merkezde tövbe, zikir, ibadet, sohbet gibi bir dizi dini içerikli ritüeli yerine getirmek için de istekli oldukları söylenebilir. Ayrıca iyileşmek için merkeze gelen bireyler buradaki dinsel ritüelleri yapmayı kabul etmekle birlikte burada olağanüstü bir metafizik gücün de kendilerine yardımcı olabileceği kanaati içindedirler. Bu inanç biçimi, bireylerde güçlü bir motivasyon kaynağını oluşturmaktadır.

Motivasyon aşamasının ilk aşamasını tövbe almak oluşturmaktadır. Daha sonra ise bu motivasyonun sürdürülmesi için dinsel ibadetlerin yerine getirilmesi aşaması izlemektedir. Tövbeden sonra, namaz, Kur'an, zikir, tesbihat, teveccüh, tevessül, rabıta, hatme, sohbet ve hizmet gibi ibadetler burada yapılması gerekenler listesinde yer almaktadır. Burada bu ritüellerden tövbe, hatme ve sohbetlerin ne olduğu, rehabilitasyon merkezinde kalan gençler için bu dinsel ritüellerin ne anlam ifade ettiği ve görüşmecilerin konuya ilişkin görüşleri aktarılacaktır.

Tövbe sözlükte "pişmanlık, dönme, nedamet" anlamına gelmektedir. İslami bir kavram olarak ise; kulun işlediği kötülük ve günahlara pişman olup, onları terk ederek Allah'a yönelmesi, emirlerine uymak ve yasaklardan kaçınmak suretiyle Allah'a sığınarak bağışlanmasını dilemesi anlamına gelmektedir. İslam'da günahlardan dolayı tövbe etmek farzdır. Kur'an'da tövbe hususu çokça geçmektedir. Tövbenin günaha pişmanlık duymak, günahı derhal terk etmek ve bir daha eski hale dönmemeye azmetmek gibi bir kısım şartları vardır. Tövbenin insanı hayata yeniden bağlayan, ona ümit ve yaşama isteği veren bir fonksiyonu vardır (Canbulat, 2006)

İslami literatürde tövbe bireysel, kişinin kendi başına yapabileceği bir iştir. Ancak tarikat geleneğinde tövbe, manevi büyükler huzurunda, onlar şahit tutularak ve vesile edilerek yapılmaktadır. Tarikatta tövbe mürşid terbiyesine girmenin ilk basamağıdır. Tövbe mürşide değil, Allah'a yapılmaktadır. Mürşid'in günahları affetme yetkisinin olmadığı, günahları yalnızca Allah'ın affettiği, mürşidin bir müminin affedilmesi için Allah'a yönelip yalvardığı kabul edilmektedir.

Mürşidle birlikte yapılan tövbenin iki önemli yönü vardır. İlki, günahlardan tövbe, diğeri ise tövbeyi korumak için mürşide intisap etmek, bağlanmaktır. Mürşidle birlikte Allah yolunda yürümek için yapılan bu manevi sözleşmeye intisap, inabe, el alma, manevi terbiyeye girme de denilmektedir.

Madde kullanmaktan uzaklaşmaya karar veren ve merkeze kabul edilen kişiler için en önemli olay tövbe almak ve mürşidin manevi terbiyesine girmektir. Gelenler ilk günlerde rehabilitasyon merkezinde Menzil'e bağlı mollalardan ya da direk Menzil'e giderek orada Şeyhin Halifelerinden tövbe almaktadırlar. Görüşülen bireyler tövbenin kendileri için önemini, kendilerine kazandırdığ1 motivasyonu ve verdiği ümit konusundaki görüşlerini şöyle ifade etmektedir:

1. E. Ö.: "Tövbe almasaydım burakamazdım. Gavs Hazretlerinden tövbe almasaydım, yine başlardım. 3 aydır içmiyorum daha da içmeyeceğim."

2. A.E.: “Gelir gelmez tövbe aldım. Günahlarımın silineceğini düşününce mutlu oldum, huzur buldum. Okuduğum kitapların çok faydası oldu”

3. M.K. : "Tövbe edince, geçmişteki hataların silineceğini söylediler ve bu beni etkiledi. Önceden inanmazdım. Rabıta, hatme gibi şeyler de etkili oluyor, bana anlattılar ve ikna oldum, sonra iyi geldi"

4. M.P.: “Geldiğimde tövbe aldım, adabımı yerine getirdim. Tövbe'den sonra artık bir daha içmeyeceğimize inancımız artıyor.”

5. A.D.: "Tövbe almak içimi ferahlatt, kalbimdeki kötülüklerin hepsini sildim. İlk burada tövbe aldım daha sonra Menzil'de. 


\section{F.Ü. Sosyal Bilimler Dergisi 2016-26/2}

Menzil tarikatında tövbe almak büyüklerin huzurunda yapılan ve belirli adabı olan bir ibadettir. Burada, ziyaretçilerin ve tövbe almak isteyenlerin sayısının çok fazla olması tövbe almayı adeta bir seremoniye çevirmiştir. Başlangıçta şeyh ile mürid arasında el ele tutuşarak ve müridin şeyhin söylediklerini tekrarlaması ile yapılan uygulama şimdi aşırı talep ve zaman darlığı nedeniyle topluca yapılmaktadır. Tövbe konusunda bir görüşmecinin aktardığı bilgiler konu hakkında açıklayıcı bir çerçeve sunmaktadır:

"Şeyhin ya da vekilinin elinde birden fazla ucu olan bir ip var. Yaklaşık 20 kişi bu ipin uçlarından tutarak irtibat kuruyor. "Yarabbi! Bütün yaptığım günahlardan ben pişmanım. Keşke yapmasaydım. İnşallah bir daha ben yapmayacağım” sözlerini söylüyor. İpin ucundan tutanlar da bu sözleri tekrar ediyor. Daha sonra tövbe adabı anlatılyor. Tövbe alanlar, tövbe aldıkları günün gecesinde belli işlemleri yerine getiriyor (M.P.).

M.P'nin belirttiği tövbe adabının sekiz şartı bulunmaktadır. Nakşî-Halidî yolunda bir mürşide intisap edince, mürşidin manevi terbiyesi ve tasarrufu altına girmek, yola gelmek için "sekiz şart" denilen adaba noksansız bir şekilde uymak gerekir. Geceleyin yerine getirilecek bu şartlar sırasıyla şöyledir.

Küçük Taharet: Tövbe niyetiyle ve yıkanan, uzuvlarla işlenmiş günahlardan arınma niyaziyla abdest almak.

Büyük Taharet: Tövbe niyetiyle ve kendisinin dışını temizlediği gibi, Cenab-1 Hak'tan da vücudunun içini temizlemesini niyaz ederek gusül abdesti almak.

İstihare Namazı: Fatiha'dan sonra ilk rekâtında Kâfirûn, ikinci rekâtında İhlâs suresini okuyarak iki rekât istihare namazı kılmak ve namaz sonunda girdiği yolun hayırlara vesile olması için dua etmek.

Tövbe: Daha önce mürşid huzurunda yapılan tövbeyi, samimi bir pişmanlıkla kendi duyacağı bir sesle üç defa tekrarlamak.

İstiğfar: Gözleri kapatarak ve önceden işlediği günahları pişmanlıkla hatırlayarak yirmi beş kere "estağfirullah" demek.

Fatiha: Gözler kapalı halde sekiz adet Fatiha okuyarak bunları Resulullah'ın (s.a.v.), Ehl-i Beytinin, ashabının ve sırasıyla silsiledeki Sâdât-1 Kiramın ruhlarına hediye eylemek.

Ölüme Rabıta: Gözleri kapatıp sekerat halinden kabirdeki ahvaline kadar her aşamasıyla kendi ölümünü düşünüp fanilik hissini hakka'l yakin tatmaya, dünyaya bağlllıktan kurtulup kalbi yumuşatmaya çalışmak.

Mürşid Rabıtası: Yine gözler kapalı halde iken, mürşidini karşısında heybetle oturur vaziyette hayal ederek ondaki feyiz ve nurdan istifadeye çalışmak. Mürşid rabitasından sonra yeniden yirmi beş defa "estağfirullah" denilerek gözler açılır ve o gece güneş doğuncaya kadar bir şey yiyip içilmez, dünya kelamı konuşulmaz (Yaşar, 2013).

Kimi görüşmeciler tedavi süreci boyunca manevi motivasyonu sürdürebilmek için her Cuma namazında Menzil'e tekrar tövbe almak için gidildiğini, burada Şeyh'in bizzat kendisi ya da vekillerinden birinin namazdan sonra kendileri gibi madde bağımlılarını gruptan ayırarak konuya ilişkin bir sohbet gerçekleştirildiğini ifade etmişlerdir.

Yeni intisap ederek sekiz şartı yerine getirenlere hatme ve rabıta talimatı verilir, bunların yapılış şekli anlatılır. Rehabilitasyon merkezinde kalan gençler, bu tövbeden sonra rehabilitasyon merkezinin kuralları ve yaşam biçimi içerisinde sosyal çevreden izole bir yaşantıyı kabul etmektedirler.

Tarikat bağlılı̆gı tövbe ile başlayan madde bağımlısı gençlerin ikinci önemli motivasyon kaynağ 1 da rabıtadır. Sözlükte "bağ, ilişki" anlamına gelen rabıta, tasavvufta, müridin, zihni planda 
tefekkür ve muhayyile gücünü kullanarak mürşidiyle beraberlik halinde olması demektir. Rabita manevi birlikteliktir. Daha çok Nakşibendiyye geleneğinde görülür (Canbulat, 2006, Rabıta).

Nakşibendiyye silsilesinden gelmekte olan Menzil tarikatında da rabıtanın önemi büyüktür. Burada iki çeşit rabıta vardır. Tövbe adabından olan "ölüm rabıtası" tövbeden sonra gece yapılmaktadır.

"Tövbe'den sonra mürşidimizle rabıta kuruyoruz, 8 Fatiha hediye ediyoruz, öldüğ̈̈müzü düşünü̈уoruz.” (A.D.)

Ölüm rabıtasında, ölüm ve ölüm halleri düşünülür. Ölümü düşünmekten gaye kalbin katılığını gidermek, kalpten dünya sevgisini çıkarmak, nefsin ölümden ibret almasını sağlamak, yaptığı ibadetlerde samimiyeti (ihlas) yakalamak ve tövbenin bozulmamasını sağlamaktır.

Diğer rabıta çeşidi tövbe adabının yerine getirildiği gece ve sonrasında günlük olarak, genelde akşam namazından sonra gözler kapalı şekilde yapılan ve yine mürşidi ile beraber olmanın hayal edildiği, onun manevi desteği ve himayesine sığınıldığı "mürşid rabıtası"dır.

“Akşam namazından sonra rabıta yapıyoruz. Rabıta'da gözlerimizi kapatıp 25 kez "estağfirullah” çekiyoruz. Hayal ediyoruz ki Gavs Hazretleri karşımızda. Onu hayal ediyoruz. 5 dakika kadar bekledikten sonra tekrar 25 “estağfirullah” çekip gözlerimizi açıyoruz” (M.P.).

M.K. rabıtanın kendisine sıra dışı duygular hissettirdiğini şu sözlerle anlatmaktadır. "Rabıta, anlatılmaz. Farklı hislere giriyorum. İyi hissediyorum. 1-2 gün yapmadım, sıkıntı hissettim." (M.K.)

Rabıtanın motivasyon açısından önemli bir fonksiyonu vardır. Belli bir terbiye içerisinde, düzenli olarak mürşidin hatırlanması, özellikle tövbe etmiş olanların tövbelerini hatırlamalarına, manevi anlamda gözetim altında olduklarını düşünmelerine sebep olmaktadır. Bu da tövbe ile başlayan motivasyonun sürdürülmesini sağlamaktadır.

"Seyrü sülûk usullerine göre tarikatlar ruhanî ve nefsânî diye sınıflandırılır. Ruhanî usulde ruh evrâd ve ezkârla güçlendirilerek kötülük odağ 1 olan nefis etkisiz duruma getirilmeye, nefsânî usulde nefis birtakım riyâzet ve mücâhedelerle doğrudan etkisiz kılınmaya çalışılır." (Öngören, 2011: 96). Menzil tarikatında zikir kalbî, sessiz ve hareketsiz olarak yapılmaktadır. Bu zikirlerin başında da hatme gelmektedir. M.P. hatme'yi söyle anlatmaktadır:

“íkindi namazından sonra halka oluyoruz. Daha önce içinde yüz taş olan bir kâse var. Bu taşları aramızda bölüş̧ї̈rüyoruz. Gözlerimizi kapatıyoruz ve Molla'nın dediklerini tekrar ediyoruz. Elimizdeki taş kadar "Ya Bakî, Ente-l Bak'i”" diyoruz ve salavat getiriyoruz. Salavat bittikten sonra herkesin gözleri kapalı halde iken molla elindeki taşları önündeki kâseye koyuyor ve yanındakine uzatıyor. Kâsenin uzatıldığını dizlerine değen kâseden anlayan kişi de elindekileri koyarak kâseyi öte yanındakine uzatıyor. Bu şekilde herkes elindeki taşları dizlerine dokundurularak uzatılan kâseye koyuyor. Kâse tekrar mollaya ulaşınca, molla gözleri kapalı halde bir miktar Kur'an okuyor, sonra "estağfirullah" diyor. Hepimiz içimizden 25 defa “estağfirullah” dedikten sonra gözlerimizi açıyoruz. (M.P.)

$\mathrm{Bu}$ anlatımdaki, gözler kapalı olduğu halde, kâsenin uzatılarak taşların toplanması esnasında kurulan sözsüz iletişime dikkat çekmek gerekmektedir. Bu iletişim biçimi grup üyeleri arasında dokunmaya ve beden dili ile anlaşmaya yol açtığı için grup birlikteliğine ve uyumuna önemli bir katkı sunmaktadır.

Yapılan görüşmelerde görüşmeciler, hatmenin önemini belirtmişlerdir:

“Hatme'nin sevabı çok büyü kmüş. Rabıta sünnetmiş, hiç terk etmiyorum.” (A.E.) “Namaz, hatme, rabıta gibi şeyler değişik ve güzel geldi" (M.K.). Rabıta, hatme gibi şeyler de etkili oluyor, bana anlattlar ve ikna oldum, sonra iyi geldi” (A.D.) 


\section{F.Ü. Sosyal Bilimler Dergisi 2016-26/2}

Rehabilitasyon merkezinde değerler eğitimini amaçlayan düzenli sohbetler de gerçekleştirilmektedir. Bu sohbetlerde Kur'an'dan, Peygamber hayatından, sahabe ve tarikat büyüklerinin hayatlarından dersler verilmekte, tarikat büyüklerinin menkıbeleri ve nasihatleri anlatılmaktadır. Sohbetler, dini bilginin artmasına, tarikat ve grup bağının güçlenmesine, ahlaki değerlerin paylaşılmasına ve motivasyonun arttırılmasına katkı sunmaktadır.

"Hatme'den sonra sohbetler oluyor. Sohbetlerde Peygamber Efendimizin (S.A.V.) hayat anlatıltyor. Öğ̈̈tler veriliyor.” (M.P.)

Madde bağımlılarının eski sosyal çevrelerine ve riskli ilişkilerine geri dönmemeleri için yatılı süreç tamamlandıktan sonra da sohbetler yoluyla bu çevre ile irtibatları devam ettiriliyor.

\subsubsection{Firsat Azaltma}

Rehabilitasyon merkezinde kalan uyuşturucu bağımlılarının iyileştirilmesine ilişkin çalışmaların yalnızca dinsel temelde olmadığı modern tedavi yaklaşımlarının tekniklerinden de yararlanıldığ 1 tespit edilmiştir. $\mathrm{Bu}$ çerçevede inanç odaklı yaklaşım çerçevesinde dinsel etkinliklerin ve programların yanında, bağımlıların anti-sosyal eğilimlerinin ve ilişkilerinin sürdürülmesini önlemek, problemli davranışların önüne geçmek amacıyla alınmış bir dizi önlem bulunmaktadır.

Cohen ve Felson tarafından geliştirilen ve suçluluğu açıklamada önemli teorilerden biri olan Rutin Aktiviteler Teorisi suç olayının meydana gelmesi için üç temel bileşenin bir araya gelmesi gerektiğini varsaymaktadır (Bkz. Kızmaz, 2005a). Bunlar; motive olmuş suçlu, uygun hedef ve suçlunun hedefe ulaşmasını engelleyecek koruyucuların yokluğudur. $\mathrm{Bu}$ üç bileşenin bir araya gelmesinin engellenmesi halinde suçun önlenebileceği kabul edilmektedir. Burada vurgulanan asıl konu, suç firsatlarının ortadan kaldırılması ya da azaltılması yoluyla suçun önlenmesidir.

Madde kullanımı ve bağımlılıkla ilgili de benzer bir durumdan söz edebiliriz. Uyuşturucu ve uyarıcı madde bağımlılığında; bağımlı, uyuşturucu madde ve kullanma firsatlarının bir arada olması madde kullanımının sürdürülmesini önemli ölçüde etkilemektedir. Özellikle madde kullanımına yönelik biyolojik, psikolojik arzular ve yoksunluk belirtileri, arınma/tam ayıklık dönemine kadar bu ilişkiyi kırmayı, madde kullanım fırsatlarını azaltmayı gerektirmektedir. İnanç odaklı yaklaşımın uygulandığ 1 rehabilitasyon merkezinde de kişilerin madde kullanma ve suç işleme fırsatlarını azaltmak amacıyla, yatılı süreç boyunca, izolasyon, kapalı devre kamera sistemleri, madde kullanım tetkikleri gibi denetim ve gözetim tedbirleri uygulanmaktadır.

Araştırma kapsamında görüşülen bireylerin kaldıkları Kardelen Rehabilitasyon Merkezinin en önemli özelliği yatılı olmasıdır. Sağlık Bakanlığı'na bağlı hastanelerde yatarak tedavi hizmeti verilmekteyse de, içerik bakımından ikisi arasında önemli farklar bulunmaktadır. Burada benzer problemleri yaşayan ve benzer niteliklere sahip bağımlılar bir arada kalmaktadır. Süre, hastanelerde olduğundan çok uzun, ilişkiler daha yakın ve samimi, görevlilerin yaklaşımı ise resmiyetten uzaktır.

M.P. "Buradaki tedavilerin diğer yerlerdeki tedavilerden çok farkı var; ilaç yok, namaz, hatme, rabıta var. Hastane, otel gibi bir ay kalırsın, çıkar gidersin. Buradakiler istediğin kadar kal diyor. Ne zaman kendine güvenirsen o zaman çık diyorlar.” (M.P.) sözleriyle uygulamanın farklılı̆̆ını ortaya koymaktadır. A.D. ise samimiyet hususunu şöyle açıklamaktadır; "Buranın farkı cana yakın olmaları. Abimizden daha yakınlar bize. Samimi bir ortam var.” (A.D.)

Öte yandan yatılı olarak kalınan rehabilitasyon merkezinde, temizlik, yemek, bulaşı gibi birçok görev ortak olarak yerine getirilmekte, gençlere sorumluluk yüklenmektedir. Rehabilitasyon merkezinde kalanlar uygulamanın yatılı olmasının önemini özellikle riskli çevreden uzaklaşma fonksiyonu üzerinden sık sık vurgulamışlardır.

"Buraya hiç gelmeseydim, orada (İstanbul) olsaydım bırakamazdım. Dışarısı ile irtibatım olsaydı, başarılı olamazdım.” (A.E.) 
Madde Bağımlılı̆̆ı Ile Mücadelede İnanç Odaklı...

\begin{abstract}
"Dışarı çıkamıyorsun, kimseyle ilişsi kuramıyorsun, arkadaş çevresinden uzak kalıyorsun; bu nedenle benim de aklima yattı." (M.K.)

"Yatılı olması daha iyi, dışarı çıkmamak daha iyi. Yeni hasta olduğumuz için yine eski ortama dönebiliriz.” (M.P.)
\end{abstract}

Rehabilitasyon merkezinde madde kullanma ve suç işleme fursatlarının azaltılması konusunda alınan denetim ve gözetim tedbirleri önemli bir yer tutmaktadır. Rehabilitasyon merkezi bir binanın 3. 4. ve 5. katlarında olup dış kapısı daima kilitli, giriş çıkışları kontrol altında tutulmaktadır. Kalanların dışarıdan gelenlerle ilişki kurmamaları özellikle maddeye ulaşamamaları için sıkı önlemler alınmaktadır. Uyuşturucu bağımlılığın tedavisi sürecinde belli bir aşama kat edemeyenlerin haftalık izinlere çıkılmasına izin verilmemekte, aile/ev ziyaretlerine de birkaç hafta sonra ailelerin gelip almaları ve geri getirmeleri koşuluyla izin verilebilmektedir.

Olası madde kullanımının, kavga, hırsızlık gibi riskli durumların önüne geçmek için yatakhane dahil merkezin her yeri kapalı devre kameralarla takip edilip kayda alınmaktadır. Ayrıca, telefon, internet gibi iletişim araçları ile dışardaki bireylerle irtibat kurmayı sağlayacak araçları kullanmak ve dışarı çıkmak ta, merkezin aldığı yasaklar kapsamındadır. Riskli ilişkileri sonlandırmak ve madde temin etme imkânlarını ortadan kaldırmak için arkadaş ziyaretleri de yasaklanmış durumdadır. Yalnızca aile ziyaretlerine izin verilmektedir. Görüşmeler esnasında bireylerin, rehabilitasyon merkezindeki sıkı denetim ve gözetimin kendi yararları için olduğu yönünde görüşler belirtikleri tespit edilmiştir:

“Gözetimin faydalı olduğunu düşünüyorum. Kavga dövüş azaltyor, bir şey yapan olursa görüyorlar.” (E. ̈.)

"Yatılı kalanlar da izinde içebilir. Hazır olmayanları izne çıkartmıyorlar. Güvendiklerini çıkartıyorlar, onlar da içmiyor.” (A.E.)

"Kameralar ve ses kayttlart son derece etkili oldu. Önce ses kaydt yoktu. Eskiden arkadaşlar yatak odasında o muhabbetleri (madde kullanımı ve keyif verici yanları) açıyorlardı. Canımız çekiyordu. Ses kayıtları alınmaya başlayınca bunlar kesildi.”(A.E.)

"Kameraların olması bize zarar verecek konuşmaların yapılmasını önlüyor. Biz bırakmaya çalışıyoruz, gelip yaralarımızı tazeleyenler oluyor. Bu türden konuşmaları engelliyor.” (A.D.)

Ancak bir kaç kişi de, kameralarla gözetimin ve izolasyonun yararları kadar rahatsızlık verici tarafları da olduğunu ifade etmiştir. Mahremiyetin azalması, iyi arkadaş ilişkilerinden mahrum kalmak ve aşırı denetimin yarattığı güvensizlik duygusu şikâyetlerin başında gelmektedir.

Merkeze kabul edilenler ve yatılı süreci tamamlayarak ayrılan ancak rehabilitasyon merkezi ile irtibatlı olmaya devam edenler 2 haftada bir madde tarama testlerinden geçirilmektedir. Maddenin idrar yoluyla tespit edildiği süreye göre sıklığı belirlenen tetkiklerde sıkı önlemler alınmaktadır. Merkezde çalışan bir görevli gözetiminde hastaneye götürülen bağımlılar, idrar alma aşamasında dahi görevlilerin gözetiminde olmaktadırlar.

Merkezde kalanların, madde kullanım tetkikleri konusundaki yaklaşımları da genel olarak olumludur.

"Haftada bir veya iki haftada bir tahlil vermeye gidiyoruz. Dışarıdan kurslara devam edenlerden içen oluyordu. Tahlillerde çıkıyordu. $O$ zaman bize zarar vermesinler diye onlar uzaklaştırıldı." (A.E.) (M.K.)

"Tahlillere götürülmesini doğru buluyorum, merak etmeleri, denetlemeleri iyi bir şeydir."

“Haftalı tahliller, izinlerde madde kullanmayı engelliyor.”(E.Ö.) 


\section{F.Ü. Sosyal Bilimler Dergisi 2016-26/2}

A.D. madde kullanım tetkiklerinin bir başka boyutunu vurgulamıştır. "Kullanmadığımızın ispatlanması kendimize olan güvenimizi de arttıryyor. Daha iyi hissediyoruz.” (A.D.)

\subsubsection{Rehabilitasyon}

Rehabilitasyon merkezinde kalanlara motivasyon kazandırılması, denetim ve gözetim yoluyla madde kullanım firsatlarının azaltılması kişilerin bağımlılıktan kurtulması için yeterli olmamaktadır. $\mathrm{Bu}$ nedenle kişilerin hem yatılı süreci daha iyi geçirmeleri, hem geçmişten getirdikleri olumsuz etkilerden kurtulmaları, hem de kendilerini geliştirmeleri için etkili bir rehabilitasyon programı uygulanmaktadır. Bunların başında değerler (ahlak ve ibadet) eğitimi, meslek edindirme kursları ve sosyal kültürel aktiviteler gelmektedir. Bu sürecin sonunda önceki yaşamlarında madde kullanıcısı, madde bağımlısı veya suçlu olarak etiketlenmiş olan kişiler yeni bir başlangıç için firsat bulduklarını düşünmektedirler.

Yatılı süreçte rehabilitasyon merkezinde kalan tüm bağımlılar, dini yönü ağır basan bir değerler eğitimi programından geçmektedirler. Namaz kılmak, kuran okumak, ilmihal bilgileri öğrenmek yatılı sürecin önemli unsurları arasında yer almaktadır. Öte yandan tarikat geleneğinde önemli bir yeri olduğunu belirttiğimiz ve mürşide bağlanmanın gerekliliklerinden olan zikir, tesbihat, rabıta, hatme gibi grup halinde ya da kişisel olarak yerine getirilen çeşitli ibadetler de ögretilmektedir.

Genelde sabah başlayıp öğle sonrasına kadar devam eden bir dini ders ve sohbet saati programı bulunmaktadır. Menzil 'den eğitim almış bir mollanın takip ettiği bu programda namazlar mollanın imamlığı ile cemaat halinde kılınmaktadır. Namazlardan sonra tesbihat, ikindi namazından sonra hatme, akşam namazından sonra da rabıta yapılmaktadır.

Rehabilitasyon merkezine geldiklerinde çok temel dini bilgilerden dahi habersiz olan gençlerin bir kısmı namaz kılmak, Kur'an okumak gibi şeylerle ilk defa burada karşılaştıklarını belirtmişlerdir.

"Sohbetlerde bilmediğim şeyleri öğreniyorum. Inancım artıyor. Yanlışlarımı görüyorum, düşüncelerim değişiyor.” (M.K.)

“Namaz kılmayı bilmiyordum, Fatiha'yı bilmiyordum, burada çok şey öğrendim. Kur'an dersi, ilmihal dersleri yaptyoruz. Namazlarımız kılıyoruz. Sohbetler oluyor. Sohbetlerde Peygamber Efendimizin (s.a.v.) hayatı anlatılyyor. Öğ̈̈tler veriliyor.”(M.P.)

"Hocaların anlattıkları, kitaplardan okuduklarım, inançla ilgili şeyleri öğrendim. Cenneti, cehennem korkusunu öğrendim. Bunlar üzerimde etkili oldu.” (A.E.)

"Daha önce ibadetleri biraz, biliyordum, ama uygulamiyordum, umursamiyordum. Annem bana namaz kul diyordu, abdest almadan odama gidiyor kıltyormuş gibi yapıyordum. Burada ibadetlerin önemini kavradık ve uyguluyoruz. Günahların ne büyük sonuçları olduğunu öğrendik.” (A.E.)

"Bunları yapınca onların verdiği ferahlığı ve güzelliği hissediyorum. Bunlar sayesinde hayatımda birç̧ok şeyin değişstiğini düşü̈nüyorum. Aile ilişkilerim düzeldi, benden uzaklaşanlar geri bana döndï" (A.D.)

Bağımlıların yatılı süreç ve sonrasında uzun süre irtibatta kaldığı rehabilitasyon merkezinde çeşitli finansman imkânları ile (İş-Kur, Halk Eğitim gibi) eğitim faaliyetleri ve mesleki kursları düzenlenmektedir. $\mathrm{Bu}$ kurslar boyunca katılımcıların mesleki yeterliliklerinin geliştirilmesi, zamanlarını verimli geçirmelerinin sağlanması, kendini gerçekleştirme ve yeteneklerini keşfetme imkânının sağlanması amaçlanmaktadır. Öte yandan bazı projelerle katılanlara cep harçlı̆̆1 verilmektedir. Mesleki kurslar bünyesinde; ahşap oymac1lık kursu, resim kursu, bilgisayar, masa tenisi, havalı okey gibi kültürel ve sportif etkinlikler bulunmaktadır. Hafta içi her gün akşam yüzme etkinliği, Pazar günleri halı saha maçları yapılmaktadır. Mevsim uygun olduğunda iki haftada bir pikniğe, Cuma günleri Menzil'e dergâha ve zaman zaman Menzil'e bağlı diğer bireylerin evlerine 
davet edilerek gidilmektedir. Rehabilitasyon merkezinde kalanlar bu faaliyetlerin kendileri için çeşitli faydaları olduğunu ifade etmişlerdir. Bunların başında maddeyi unutmak ve iyi zaman geçirmek gibi hususlar gelmektedir:

"Kişinin bir şeyle uğraşması kafasını dağıtır. Yaptığı işsen zevk alırsa, madde kullanmak aklına gelmez." "Yapılan faaliyetler güzel. Ahşap oymacılık kursu hoşuma gitti. Zaman geçirmek için ideal, yeni bir şey öğrenmek güzel, zevkle yapıyorum.” (M.K.)

"Burada televizyon izliyoruz, sohbet ediyoruz, masa tenisi oynuyoruz. Oymacılıkta aklıma gelen her şeyi tahta üzerine yapıyorum.” (E.Ö.)

“Gün içinde ahşap kursu, Kur'an dersi, ilmihal dersleri yapıyoruz. Öğle namazından ikindiye kadar yemek ve serbest zaman (bilgisayar, tenis, televizyon vs.) etkinlikleri ile geçiriyoruz. Bu etkinlikler günümüzzün sorunsuz geçmesini sağllyor.” (M.P.)

"Stres atmak ve kendimizi oyalamak için günlük faaliyetlerin önemli katkısı oluyor.” (A.D.)

\subsubsection{Yeniden Sosyalleştirme, Etiketlenmeye Karşı Yeni Bir Fırsat}

Madde bağımlıları için en önemli sorunlardan biri etiketlenmektir. Uyuşturucu ve uyarıcı madde kullanma alışkanlığı genelde problemli bir sosyal çevrede edinilip sonrasında yine bu çevrenin etkisiyle sürdürülmektedir. Toplum içerisinde hoş karşılanmayan bu davranış1 gerçekleştirmek, çoğunlukla etiketlenmeye ve sosyal çevreden dışlanmaya yol açmaktadır. Kişi hem kendisinin madde kullanımından dolayı hem de içinde bulunduğu problemli kişilerin hoş karşılanmayan davranışlarından dolayı toplumdan dışlanmış olma hissini yaşamaktadır.

Bağımlılıkla mücadelede en önemli zorluklardan biri bu etiketlenmeden kurtulmaktır. Sosyal çevrenin kişiye bakışını değiştirmesi hem zor hem de uzun bir zaman almaktadır. Menzil'de arınmanın bağımlılara sağladığı en önemli katkılardan biri bu etiketlerden kurtulmayı kolaylaştırmasıdır. Önceki dönemlerde suçlu, alkolik, içkici, psikopat, madde bağımlısı gibi etiketlenmiş bireyler bu yeni dönemde "tövbeli" olarak görülmekte ve muamele edilmektedir. Bu yeni etiket belli davranış kalplarıyla desteklendiğinde toplumun kişiyi kabul etmesi, yeniden sağlıklı sosyal ilişkiler kurması kolaylaşmaktadır.

Rehabilitasyon merkezinde kalan gençler bu konu üzerinde israrla durmuşlardır. Rehabilitasyon merkezinde kalmanın tüm olumlu etkilerinin yanında, Menzil'le irtibatlı olmanın ve tövbe almış olmanın kazandırdığı bu yeni etiket/imaj kendilerini iyi hissetmelerine, kendilerine güvenmelerine ve kendilerine güvenilmesine yol açmaktadır.

İstanbul'dan gelen A.E.'nin bu konuda belirtikleri son derece dikkat çekicidir:

“Ailem ve arkadaşlarım bana acayip bir gözle baklyordu. 'sen nasıl bir çocuk oldun', 'ne yaptyorsun sen' gibisinden. Ailem buraya ziyaretime geldiğinde bendeki değişikliği fark etti. Bunu diğer akrabalarıma anlatmışlar, herkes çok sevinmiş. Bana artık 'içen A.' gözü̈yle değil 'sofi A.' gözü̈yle bakıyorlar. Telefonda konuşurken bile hissediyorlar bendeki değişimi. Kuzenim Anneme A. 'nın konuşması ne kadar değişmiş' demiş. Eskiden iki lafımdan biri küfürdü. Artık hiç ă̆zıma almamaya çalışıyorum.” (A.E.)

A.E. gibi diğer bireyler (M.P. ve A.D.) de, aileleri ile aralarındaki güven ilişkisinin yeniden inşa edildiğine dikkat çekmekte, E.Ö. de kolluk kuvvetlerinin dahi kendilerine bakışının değiştiğini vurgulamaktadır:

“Gittikçe güvenleri artıyor. Ben de burada kaldıkça onlara karşı kendimi daha iyi hissediyorum.” (M.P.)

"Hem annem, hem babam çok rahat, güvenleri sonsuz. Bana bakışları değişti. Eskiden sürekli tartışırdık, şimdi telefon açıyor ve halimi soruyorlar, isteğim olup olmadığını soruyorlar... Annem çok mutlu.”(A.D.) 


\section{F.Ü. Sosyal Bilimler Dergisi 2016-26/2}

“Burada olduğumuzu gören polisler şaşırıyor. Onların hakkımızdaki fikirleri, bize bakışları değişiyor.” (E. Ö.)

Rehabilitasyon merkezinde kalmanın sosyal ilişkilerin düzenlenmesi ile ilgili ilk ve en önemli etkisi yatılı süreçtir. Bağımlıların yatılı kalmaları her şeyden önce onların riskli sosyal çevrelerinden uzaklaşmalarını mümkün kılmaktadır. Ancak yaşları son derece genç olan ve yönlendirmelere açık olan bu kişileri riskli ilişkilerden uzak tutmak yeterli olmamaktadır. Yatılı süreci tamamladıktan sonra eski yaşamlarına geri dönecek olan bağımlıların, sosyal ilişkilerine alternatifler sunulması, yeni bir sosyal çevrenin kazandırılması önemlidir. Rehabilitasyon merkezinde kalan gençlere bu fursat iki şekilde sunulmaktadır. Bunlardan ilki aile ilişkilerinin onarılması ikincisi ise Menzil bağlılarından oluşan yeni bir sosyal çevrenin kazandırılmasıdır.

Rehabilitasyon merkezinde yapılan çalışmaların önemli bir ayağı, bağımlıların genelde iyi olmayan aile ilişkilerinin onarılmasıdır. Merkeze aile desteği ile gelenler olduğu gibi, başka kanallardan yapılan yönlendirmelerle gelen ve ailesi ile neredeyse ilişkisi kesilmiş gençler de bulunmaktadır. Görevliler ile yaptığımız görüşmelerde yıllar süren problemli yaşamları ve yaşadıkları yüzünden ailesinin gözden çıkardığ 1 ve ilişki kurmaktan kaçındığı kişiler de olduğunu öğrendik. Bu nedenle aile ilişkilerinin düzeltilmesi için bazen aileyi ikna etmek ve aile nezdinde girişimlerde bulunmak gerektiği belirtilmiştir.

Aile ilişkilerinin iyileşmesi süreci, aslında gençlerin rehabilitasyon merkezinde kalmayı kabul etmeleriyle başlamaktadır. Madde kullanmaktan vazgeçmeyi kabul etmeleri, arkadaş çevrelerinden uzaklaşmaları ve tövbe alıp yaşamlarını değiştirmeye başlamaları bu ilişkilerin de yeni bir boyut kazanmasını sağlamaktadır. Ancak yine de bunun uzun süreli ve kalıcı olması için karşılıklı güven inşası gerekmektedir.

Gençler süreç içerisinde aile ilişkilerindeki değişimi fark etmekte, önemsemekte ve bunun kendileri için önemini vurgulamaktadırlar.

“Allah razı olsun onlardan... Uzak olmasının sıkıntıları da var. Ailem ile yakın olsaydım iyi olurdu. Burada onları özlüyorum.” (A.E.)

"3-4 günde bir babam - annem geliyor. Gelmelerinin faydası oluyor, bu işten uzak durduğumu görüyorlar... Ben de burada kaldıkça onlara karşı kendimi daha iyi hissediyorum... Eskiden eve gittiğimde kendimi evlatlık gibi hissediyordum. Şimdi ailemin bana benim de onlara yaklaşımım değişti. Eve gidince mutlu oluyorum, kardeşlerimle zaman geçiriyorum.” (M.P.)

"Hem annem, hem babam çok rahat, güvenleri sonsuz. Bana bakışlart değişti. Eskiden sürekli tartışırdık, şimdi telefon açıyor ve halimi soruyorlar, isteğim olup olmadığını soruyor, 'Ellerinden öperim' diyorum, bu bile yeter, çok şeye bedel. Annem çok mutlu.” (A.D.)

$\mathrm{Bu}$ araştırma sonucunda büyük bir kitleye sahip olan Menzil tarikatı ile ilişkili bir rehabilitasyon merkezinde kalmanın, benzer hizmetleri veren diğer rehabilitasyon merkezinde kalmakla aynı şey olmadığı kanaati oluşmuştur. Birçok dini cemaatte olduğu gibi Menzil'le irtibatlı olmak, kişilere Türkiye genelinde hatta yurt dışında benzer duygu ve düşünceleri paylaşan ve benzer davranışlar sergileyen büyük bir sosyal çevre kazanma imkanı sunmaktadır. Daha yakın ve daha samimi ilişkilerin yaşandığ bu sosyal çevrede olmak gençler için eski sorunlu çevreden uzaklaşma fırsatının oluşması anlamına gelmektedir. Görüşme yaptığımız kişiler çoğunlukla rehabilitasyon merkezinden ayrıldıktan sonra da Menzil ile ilişkilerini sürdürme kararlılığında olduklarını dile getirmişlerdir.

"Sohbetlere gidiyoruz, çiğköfteye çağırıyorlar. Sofiler bizi çok seviyorlar, bize saygı gösteriyorlar. Eski çevremizde sürekli aşağılanıyorduk, ama sofilerin güler yüzlü yaklaşımı, samimiyetleri bizi mutlu ediyor... Çıkınca bizim orada Menzil'in dergâhı var. Gündüz çalışmayı gece de dergâha gitmeyi düşünüyorum. Dergâha gider hatme ve diğer ibadetlerimi orada yaparım.” (A.E. 17 yaş, İstanbul) 
“Buranın farkı cana yakın olmaları. Abimizden daha yakınlar bize. Samimi bir ortam var... Ayrıldıktan sonra sohbetlere faaliyetlere devam etmeyi düşünüyorum. Menzil ile bağımı kesinlikle koparmam. Bundan sonra vakıftakiler, dergâhtakiler benim çevrem.” (A.D. 20 yaş, Adiyaman)

\section{SONUÇ}

Türkiye' de dinin sosyal yaşam üzerinde önemli bir etkisi vardır. Ülkemizde din önemli ölçüde, duygu, düşünce ve yaşam pratiklerimiz üzerinde belirleyici olan bir unsurdur. Ancak bat1 kültürünün ve pozitivist bilim anlayışının hâkimiyeti altında gelişen modernleşme tecrübesi, dinin sosyal yaşam üzerindeki bu etkisini görmezden gelmekle kalmamış onunla mücadele eden bir nitelik arz etmiştir. Dinin sosyal yaşamdan soyutlanması çabaları, modernleşen toplumda kaçınılmaz olan sosyal problemlere yenilerini eklemiştir. Benzer şekilde sosyal problemlerin çözümünde motivasyonunu dinden ve inançtan alan uygulamalar da kamusal alandan dışlanmıştır. Batı'da madde bağımlılı̆̆ıyla mücadelede önemli bir yeri olan dini gönüllü kuruluşların fonksiyonunu icra etme potansiyeli olan tarikat ve cemaatlerin bu potansiyeli yeterince değerlendirilememiştir. Menzil tarikatının madde bağımlılığı, kumar gibi kötü alışkanlıklarla mücadelede halk arasında meşhur olan konumu da bilimsel araştırmalara -neredeyse hiç- konu olmamıştır.

Madde bağımlısı bireylerin bağımlıktan kurtulmak için Menzil'e gelenlerin kolayca tedavi oldukları veya iyileştiklerine dair destekleyici değerlendirmeler olmakla birlikte karşıt tezlerin olduğu da bir gerçektir. Cemaat mensuplarına göre, bireylerin tarikata dahil olmakla bağımlıklarından kurtulmalarının dinsel bir açıklaması vardır. Burada, cemaatin manevi etkisi özellikle de bir kerametin varlığına inanılmaktadır. Karşıt argümanlar ileri süren kimileri de bu tür tedavi biçimlerini bir tür anti-bilimsel veya "üfürükçülük" olarak tanımlamaktadır. İyileşenler ile ilgili haberleri de, sadece bir şehir efsanesi niteliğinde görmektedirler. Ancak Menzil'e gelenlerin gelmeden önceki yaşamları, gelirken beklentileri, Menzil' de tecrübe ettikleri ve Menzil'den sonraki yaşamları detaylı bir şekilde ve birçok örnekle ele alındığında "Menzil'de arınma/iyileşme" inanışının manevi etkiden uzak olmayan sosyal bir gerçeklik olduğu anlaşılmaktadır.

Aslında sözü edilen cemaat veya derneklerdeki rehabilitasyon sürecinin tümüyle dinsel bir nitelik arz ettiğini söylemek mümkün değildir. Dinsel cemaat veya bunlara bağlı dernekler kapsamında sürdürülen faaliyetlerin veya programların bazıları son derece modern tedavi tekniklerini de kullanan bir işleyişe sahiptir. Ancak süreç içerisindeki aşamalar motivasyonunu daima inançtan ve teslimiyetten aldığı için işin manevi boyutu son derece önemlidir. Bu gerçekliğin daha net ve kurumsal tezahürü, Menzil'le irtibatlı madde bağımlılarına hizmet veren rehabilitasyon merkezlerinde görülmektedir.

Araştırmaya konu edilen Rehabilitasyon Merkezi faaliyetlerine henüz yeni başlayan ancak yaygınlaşma potansiyeli olan bir uygulama olarak dikkat çekmektedir. Şanlıurfa, Viranşehir, Adıyaman ve Tokat'ta STK'lar bünyesinde kurulan bu merkezler Bağımlılıkla Mücadelede İnanç Odaklı Yaklaşıma önemli bir örneklik teşkil etmektedirler.

Adıyaman'da faaliyet gösteren Adıyaman Kardelen İzcilik Gençlik ve Spor Kulübü Derneği bünyesinde kurulan Madde Bağımlıları Rehabilitasyon Merkezi’ndeki uygulamada her bir süreç ayrı önem arz etmektedir. Öncelikle Menzil'e gelenlerin çoğunlukla madde kullanımı konusunda rahatsızlık duyan ve bundan kurtulmak isteyen kişiler olduğu göz önüne alınmalıdır. Belirli bir farkındalık düzeyine erişmiş olan bu bireyler bağımlılıktan kurtulmak konusunda karar aşamasındadırlar ancak başarılı olabileceklerine dair özgüvenleri zayıf olduğu için destek arayışı içerisindedirler.

Bu aşamada Menzil'den aldıkları manevi destek, onları bunu yapabilecekleri konusunda motive etmekte ve cesaretlendirmektedir. Tövbe almak ve bir mürşidin himayesine girip ona teslim olmak şeklindeki tasavvufî ilke kendi iradeleri ile maddeyle başa çıkamayan bağımlılara güç ve moral vermektedir. Bir mürşidin yol göstericiliğinde yeni bir hayata başlama fikri bağımlılıkla 


\section{F.Ü. Sosyal Bilimler Dergisi 2016-26/2}

mücadelenin ağır yükünü hafifletmektedir. Ancak uygulama yalnızca bu motivasyonla kalmamakta, motivasyonun sürdürülmesi ve madde kullanıcılarının karşılaştığı birçok güçlüğü aşacak şekilde kurumsal bir destek sağlanmasıyla süreç işlemektedir.

Sürecin bundan sonraki aşamaları firsat azaltma ve rehabilitasyonu içermektedir. Madde Bağımlıları Rehabilitasyon Merkezi fiziki yapısı, kuralları ve işleyişi ile yatılı olarak kalan bağımlıların madde kullanma firsatlarını ortadan kaldırmaya çalışmaktadır. İhtiyaç duyanlar tedavi ettirilmekte, diğerlerinin maddeye ulaşmasını engellemek için dış dünya ile kontrollü ilişkiler kurulması sağlanmaktadır. Yatılı süreç, giriş çıkışların kontrol altına alınması, kapalı devre kamera sistemleri, ziyaret yasakları, madde kullanım tetkikleri vb. denetim ve gözetim tedbirleri ile kişiler, riskli sosyal çevreden ve riskli davranışlardan uzak tutulmaya çalışılmaktadır.

Madde bağımlısı gençlerin rehabilitasyonu için de çeşitli çalışmalar yapılmaktadır. Meslek edindirme kursları, kültürel etkinlikler ve gezi, spor seyahat gibi boş zaman etkinlikleri ile rehabilitasyon merkezinde kalanların uyum sorununu aşmalarına, madde kullanma ihtiyaçları ile baş etmelerine, psikolojik olarak kendilerini iyi hissetmelerine ve gelecek beklentilerinin artmasına katkı sunulmaya çalışılmaktadır. Bu çalışmaların gençler üzerinde olumlu etkiler bıraktığı ve ümitlerini arttırdığı yapılan mülakatlardan anlaşılmıştır.

Madde bağımlılarının rehabilitasyonu konusunda dikkat çekici bir husus da bireylerin geçmişteki olumsuz yaftalamalardan/etiketlenmelerden kurtulmak için yeni bir firsat yakalamış olmalarıdır. Uyuşturucu ve uyarıcı madde kullanmaları nedeniyle damgalanan ve toplum tarafından kısmen de olsa dışlanan kişiler, tövbe almakla, yakın çevrelerinden başlamak üzere, insanların gözünde yeni bir kimlik ve olumlu imaj kazanmış olmakta ve eski olumsuz etiketlerinin dezavantajlarından kurtulma firsatı yakalamaktadır. $\mathrm{Bu}$ yeni konumun uygun davranışlarla desteklenmesi durumunda etiketlenmenin olumsuz etkisinin ortadan daha kolay kalkacağ 1 kanaati oluşmuştur.

Bağımlılıkla mücadelede inanç odaklı yaklaşıma örnek olarak aldığımız uygulamanın en önemli aşamalarından biri ise yeniden sosyalleştirmedir. Yeniden sosyalleştirme öncelikle aile ilişkilerinin onarılmasını hedeflemektedir. Madde kullanımı ve problemli sosyal ilişkilerinden dolayı bağımlıların büyük bir kısmı geçmişte aileleri ile ciddi sorunlar yaşamışlardır. Aileleriyle ilişkisi olanların ilişkilerinin niteliğinin arttırılmasına, ilişkisi olmayanların da rehabilitasyon merkezinde çalışan görevlilerin girişimleri ile yeniden ilişki kurmalarına çalışılmaktadır. $\mathrm{Bu}$ çabaların en önemli sonuçlarından birisi gençler ile aileleri arasında yeniden bir güven ilişkisinin tesis edilmesidir.

Menzil ile bağlantılı rehabilitasyon merkezinde kalanlar için yeni bir sosyal çevre edinme, bu programın öne çıkan bir başka önemli özelliğidir. Hem rehabilitasyon merkezindeki arkadaşlar ve görevlilerle, hem de Menzil'e bağlı olan ve bu kişilerin kazanılması için onlarla yakın ilişkiler kuran bağlılar ile (sofiler) yeni bir ilişki ağı kurulmaktadır. Menzil tarikatına bağlı cemaatin ülke genelinde yaygın olduğu ve birçok yerde dergâhlar, vakıf ve derneklerin olduğu düşünüldüğünde edinilen bu sosyal ilişkiler ağı daha da önem kazanmaktadır. Mülakat yapılan gençler, rehabilitasyon merkezinden ayrıldıktan sonra bu ilişkileri sürdürme ve eski sorunlu ve suçlu çevreleri ile aralarına mesafe koyma niyetlerini ortaya koymuşlardır.

Bağımlılıkla mücadele sorunu yalnızca tıbbi ve adli yaklaşımların çabaları ile üstesinden gelinemeyecek düzeyde ağır ve yaygın bir sorundur. Bu nedenle bağımlılık konusunda mücadele edecek gönüllü kuruluşların desteklenmesi ve mücadelenin ülke geneline yayılması sağlanmalıdır. Ülkemizde önemli bir potansiyeli olan Menzil dışındaki dini cemaatlerin ve STK'ların da bu konuda Menzil tarikatı gibi inisiyatif alması gerekmektedir. Madde kullanımının her geçen gün arttığı ve bağımlılık tedavisinin ne kadar zor ve uzun bir süreç olduğu göz önüne alındığında, sivil toplum örgütlerinin ve dini grupların bu konuda harekete geçirilmesi ülkemiz için tercih olmaktan çok bir zorunluluktur. 


\section{KAYNAKÇA}

Baier, Colin J. (2001) "If You Love Me, Keep My Commandments: A Meta-Analysis of The Effect of Religion On Crime", Journal of Research in Crime\&Delinquency, 38 (1): 3-21.

Becioğlu, A. (2014, Ocak 17). Menzil'i Bilir misiniz? 05 29, 2015 tarihinde Fatsa Güneş Gazetesi: http://www.gunesgazetesi.net/koseyazilari/2219/2528/ahmet-becioglu-menzili-bilir-misiniz.html adresinden alınd 1

Bock, E. Wilbur, John Cochran and Leonard Beeghley (1987), "Moral Messages: The Relative Influence of Denomination on the Religiosity-Alcohol Relationship", The Sociological Quarterly 28: 89-103.

Brantingham, P., \& Faust, F. (1976). A conceptual model of crime prevention. Crime and Delinquency 22, 284-296.

Burkett, Steven and Bruce Warren (1987), "Religiosity, Peer Associations, And Adolescent Marijuana Use: A Panel Study of Underlying Causal Structures", Criminology 25: 109-131.

Canbulat, M. (2006). Tövbe içinde, Dini Kavramlar Sözlüğü. Ankara: DİB Yayınları.

Chadwick, Bruce A; Top, Brent L. (1993), "Religiosity and Delinquency Among LDS Adolescent", Journal For Scientific The Study of Religion, 33 (1): 51-67.

Diyanet İslam Ansiklopedisi. (1995). EROL, Muhammed Râş̧id . Anonim içinde, Diyanet İslam Ansiklopedisi Cilt:11 (s. 305). Türkiye Diyanet Vakfi.

İlk Haber Gazetesi. (2014, 02 13). Alkolü burakmak için Menzil'e gittiler. 06 02, 2015 tarihinde http://ilkhabergazetesi.tv: http://ilkhabergazetesi.tv/alkolu-birakmak-icin-menzile-gittiler/adresinden alındı

Kızmaz, Zahir (2005a ). Sosyolojik Suç Kuramlarının Suç Olgusunu Açıklama Potansiyelleri Üzerine Bir Değerlendirme. C.Ü. Sosyal Bilimler Dergisi, 29(2), 149-174.

Kızmaz, Zahir (2005)."Din ve Suçluluk: Suç teorileri Açısından Kuramsal Bir

Yaklaşım”, Fırat Üniversitesi Sosyal Bilimler Dergisi, Cilt 15, Sayı:1.

Kızmaz, Zahir (2010), "Din ve Suç: Cezaevinde Hükümlü Bulunan Bazı Suçluların Dindarlık Durumları" Fırat Üniv. Sosyal Bilimler Araştırma Dergisi, 16: 27-58

Ögel, K. (2010). Sigara, Alkol ve Madde Kullanım Bozuklukları: Tanı, Tedavi ve Önleme. İstanbul: Yeniden Yayınları.

Öngören, R. (2011). Tarikat. Diyanet İslam Ansiklopedisi (s. 95-105). içinde Türkiye Diyanet Vakfi.

Park, Sunyoung ve Hüseyin Akdoğan (2011), "Mükerrer Suçun Önlenmesinde ve Hükümlülerin Topluma Tekrar Kazandırılmasında İnanç Odaklı Cezaevi Programlarının Rolü” Suç Önleme: Teorik, Pratik ve Değerlendirme içinde (Edt: M. Alper Sözer ve Daniel R. Lee), Ankara: Seçkin yay.

Parlatır, İ. (2011), Osmanlı Türkçesi Sözlüğü, Ankara, Yargı Yayınları

Prochaska, J. O., DiClemente, C. C., \& Norcross, J. C. (1992). In search of how people change: applications to addictive behaviors. American psychologist, 47(9), 1102-1104.

Stark, Doney (1996), "Religion as Context: Helfire and Delinquency One More Time, Sociology of Reigion 57: 163-173.

Uludağ, S. (1999), Tasavvuf Terimleri Sözlüğü, İstanbul, Marifet Yayınları

Yaşar, A.N. (2013, Ocak). Yola Gelmek, Yolda Olmak. Semerkand Dergisi.

Yaşar, A.N. (2011, Temmuz). Yolumuzu Aydınlatan Kandiller: On Bir Esas. Semerkand Dergi.

Yeni Aktüel Dergisi. (tarih yok). İşte Menzil Dergahı. 06 02, 2015 tarihinde yeniaktuel.com.tr: http://www.yeniaktuel.com.tr/tur105,71@2100.html adresinden alındı 